Miloš B. Rajković*, Dušanka Popović Minić, Danijel Milinčić, Milena Zdravković

University of Belgrade, Faculty of Agriculture, Institute for Food Technology and Biochemistry, Department of Chemistry and Biochemistry, Belgrade - Zemun, Serbia
Review paper ISSN 0351-9465, E-ISSN 2466-2585 UDC: 338.439: 663.25: 330.143.2 doi: $10.5937 /$ zasmat2003229R6

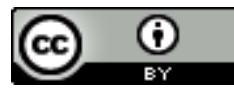

Zastita Materijala 61 (3) $229-250(2020)$

\title{
Circular economy in food industry
}

\begin{abstract}
The concept of the circular economy goes beyond the outdated idea of the linear economy, which involves the uncontrolled exploitation of natural resources, and the material flows from the factory through the user to the landfill. In the circular economy, the circle product - waste - product is closed. It is expected from the industry to function as a natural eco-system, and waste from one industry becomes a raw material to another industry, i.e. to stimulate circulation, from which the term circular originates. The circular economy is a general term that encompasses all activities that reduce, reuse, and recycle materials in the processes of production, distribution, and consumption. Taking into account the projections for population growth on Earth, the food industry is expected to increase production, which inevitably carries an increase in the amount of generated waste. Organic components of vegetable waste are of interest for further use because they contain large quantities of highly valuable molecules. This paper aimed to show that waste from the food industry is not waste but a raw material that can be incorporated into other processes, which are the basic principles of circular economy - regeneration and circulation. The wine industry, as a major industry for the grape as raw material, creates large quantities of such waste. In the literature review are provided various innovative solutions that show what to do next with wine by-products, especially grape hush. Besides using in the industry of strong drinks, through composting or as a forage supplement, new solutions are presented. They are: the hush as a significant bioenergy source; the use of the most important substances from the hush, such as polyphenolic compounds, dietary fiber, tartaric acid, oils; the hush as a raw material for the production of biofuels, enzymes, biosurfactants, etc.
\end{abstract}

Keywords: Circular economy; food industry; wine industry; pomace.

\section{INTRODUCTION - BASIC PRINCIPLES OF CIRCULAR ECONOMY}

The term economy originates from the Greek word oikonomikos and is a compound noun that originally means - the laws of household management. Since the beginning of industrialization until the end of the $X X$ and the beginning of the $X X I$ century, the economy can be considered as linear. Raw materials were available and cheap, and the question of limited natural resources was not raised. However, with the growth of production, the amount of waste also increased and people began to see the negative aspect of the industrial development on the environment. In addition to the

\footnotetext{
${ }^{\star}$ Corresponding author: Miloš B. Rajković

E-mail: rajmi@agrif.bg.ac.rs

Paper received: 02. 06. 2020.

Paper accepted: 10. 07. 2020.

Paper is available on the website:

www.idk.prg.rs/journal
}

direct influence of industry, the transition from the rural to the urban way of life and the development of consumerism also have a great impact. People live by the principle: take - use - dispose, without thinking about what happens next with that waste $[1,2]$.

With the amount of waste as well as energy demand increasing, and available natural resources limited, the usage of waste has become one of the main topics for scientists around the world. By reducing the amount of waste, we are moving towards cleaner production, which is considered a transitional phase towards zero emissions.

The concept of cleaner production, as well as the Zero Emission Concept implies a developed network between industries, their grouping and close mutual cooperation. Industries themselves are expected to modify their processes to make the most of their resources, alone or in collaboration with a network of industries, as waste can be a resource if put in the right place. 
Circular economy can be defined as an industrial system that is renewable or regenerative with intent or design, with the aim of eliminating waste through superior design of materials, products, systems and business models [3,4], or can be defined as an economic strategy proposing innovative ways for transformation of the currently

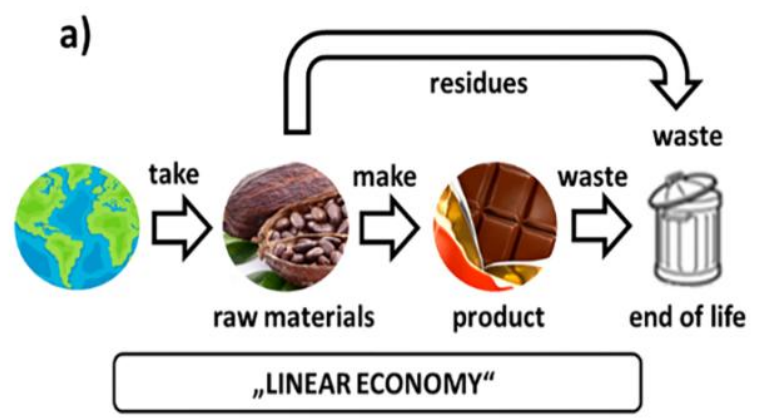

a) predominant linear system and achieving economic sustainability with material savings [5]. In general, circular economy is a general term that encompasses all activities that reduce, reuse and recycle materials in the processes of production, distribution and consumption [6]

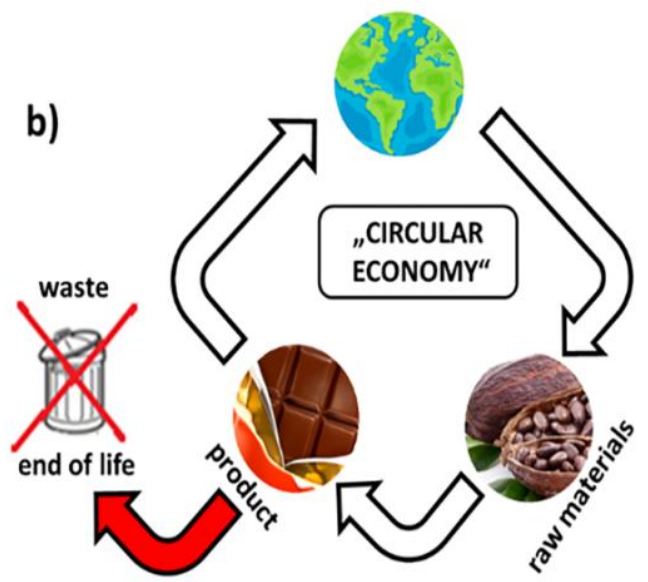

b)

Figure 1. a) Basic principle of linear economy; b) basic principle of circular economy

Slika 1. a) Osnovni princip linearne ekonomije; b) osnovni princip cirkularne ekonomije

The increasingly accepted concept of circular economy in this way goes beyond the outdated concepts of linear economy, which implies the uncontrolled exploitation of natural resources and the flow of materials from the factory through the user to the landfill [2]. This can be achieved by reducing harmful emissions, replacing nonrenewable energy sources with renewable ones, thus closing the circle: product - waste - product. Thus, the industry is expected to function as a natural ecosystem and that waste from one industry (output) becomes a raw material in another (input), ie. to imitate circulation, whence the name circular comes from [1].

The approach that involves joint action and the industrial cluster approach is something that is striven for, However, a number of issues arise, such as the appropriate size of the cluster, and then there is a limiting factor - a change in technology. How much can the existing technology of a company be changed in order to meet all the requirements, without the change having a negative impact on the company itself, etc.?

The concept of circular economy can be applied to small, medium and large enterprises. In practice, however, environmental improvements are more difficult to achieve in small and mediumsized enterprises due to limited human and material resources. Because of this, merging companies and acting together is the only way to make progress, regardless of the previously mentioned doubts.

According to the previous definitions, the goal is that industrial production based on the circular economy, in addition to its positive impact on the environment, also contributes to economic growth.

The objectives of the paper are to, using circular economics, perform [7]:

1. identification, discussion and development of various definitions that facilitate the usage of new literature;

2. proposing an initial research approach where research on the circular economy can be conducted.

Circular economy has another great advantage - it is not reserved only for the rich countries of the West. For example, China was the first country in the world to adopt a law on the implementation of the circular economy in 2008, followed by others [8]. The European Union has created a package on the circular economy by extending earlier directives on waste management. The ten-year development strategy (2010-2020) of Europe 2020, which was adopted after the global economic crisis in 2008, mentions the transition from a linear to a circular (circular) economy as one of the EU's development priorities [2]. 
Based on Germany's many years of experience in introducing a circular economy, 5 phases in the process of improving the waste management system have been defined [9]:

Phase 1 - disposal of waste in uncontrolled landfills,

Phase 2 - reliable waste collection and landfill improvement,

Phase 3 - introduction of separate waste collection and its sorting,

Phase 4 - improvement of the recycling industry,

Phase 5 - circular economy - waste as a material and energy resource.

As far as Serbia is concerned, the recommendations of the European Commission on the circular economy have been accepted, and amendments to the laws in the field of environmental protection have been adopted, including amendments to the Law on Waste Management. The National Strategy for Sustainable Development for the Republic of Serbia was adopted in 2008 and was valid until 2017. Guidelines for further action in the field of sustainable development are given here. It is important that such strategies do not remain just a dead letter, because, as a consequence of the industry based only on a linear economy, Serbia today has 3,500 illegal landfills and only 8 sanitary regional landfills. Only $5-7 \%$ of waste is recycled, while at the annual level material worth of 50 million euros is disposed of in over than 150 unsanitary landfills [9].

The aim of these measures is primarily the prevention of waste, reduction of harmful substances in it, enabling the return of products to the life cycle after it becomes waste, improving the volume as well as the quality of recycling, establishing a system of separate waste collection, introducing measures to reduce biodegradable waste at landfills by encouraging composting and anaerobic digestion.

At the state level, but also at the level of the European Union, as well as the rest of the world, discussions on this topic are more frequent, but they are still at the level of concepts and examples from practice are few. More detailed analyzes of this concept are needed, an even deeper theoretical basis, but also its practical application in industry.

\section{VALORIZATION OF WASTE AND BY- PRODUCTS IN THE FOOD INDUSTRY}

The growing production of food that is necessary to meet the needs of a growing number of people in the world involves serious environmental issues. Problems that can arise in food processing are related to energy and waste management. Large amounts of waste generated in the food industry raise important issues related to management problems, both from an economic and environmental point of view [10]. At the end of the seventies of the $X X$ century, the first researches began and the first results, which were focused on the reduction of waste and by-products in the food industry, were obtained. All these researches were aimed at valorization of waste from the food industry with the idea of making a profit in the future by using waste and by-products $[8,11]$. For example, it is necessary to take into account that the generated plant and animal material is prone to microbial spoilage. Such facts limit further valorization, while production alternatives such as drying or storage have economic constraints that limit their application [8]. Therefore, according to van der Goot et al., [12], the reduction of waste production is influenced by the improvement of the management structure and the quality of monitoring in food production chains.

In many organizations, the boundary between waste and by-products is not fixed. According to Santana-Méridas et al. [13], a waste directive has been established, distinguishing between so-called differentiating waste (material discarded by the holder), production residue (material that is not intentionally produced, which does not have to be strictly, but can be declared as waste) and byproducts (residue that can be used directly without further processing). According to Jasch, byproducts are created during the production process of the main product and they are not the primary goal of production [14], while Galanakis defines byproducts as substrates separated from the food production process where functional components can be used, thus facilitating the development of new high quality products on the market [15]. Byproducts from food production can be generally divided into two groups, depending on whether they come from food of plant or animal origin [16].

The production of waste and by-products from food follows the entire Food Life Cycle, from agriculture through industrial production, food processing and sales, all the way to household consumption [10]. In developed countries, $42 \%$ of food waste is generated in households, $39 \%$ is lost in industrial food production, $14 \%$ is generated in food service sectors and $5 \%$ is generated in retail chains and during distribution [10]. Waste and byproducts have great potential to be reused through various production systems. Given the limitations in the industry, there is a great tendency towards the possibility of using by-products and the usage of essential food ingredients, because they can be an 
important source of compounds that can partially or completely replace certain raw materials. The goal is to reduce the amount of waste through an adequately developed production strategy, and then to define the principle according to which any generated waste and by-products can be used in the production of other food or non-food products. Therefore, the implementation and realization of various initiatives at the industrial level leads to achieving maximum waste utilization or Zero Waste to Landfill. Industrial concepts of ecology such as the concept of Cradle to Cradle and the circular economy can be considered as the leading principles of ecological innovation, having in mind the so-called zero waste economy where waste serves as a raw material for new products and applications [10].

However, in order for this "Zero Waste" practice to be adequately implemented, the principle of the waste management hierarchy is very important, as shown in Fig. 2 [17].

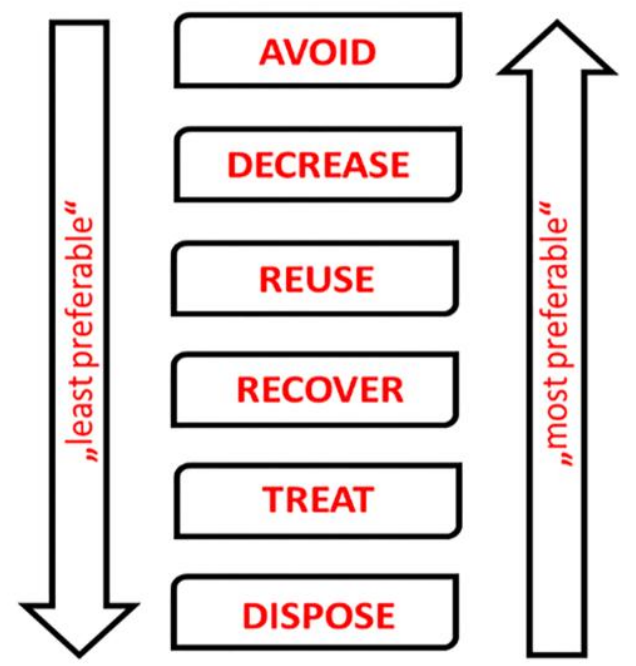

Figure 2. Hierarchy of food waste management (adapted from Kosseva, 2011) [17]

Slika 2. Hijerarhija upravljanja otpadom iz hrane (prilagođeno iz Kosseva, 2011) [17]

This principle of management, the so-called Green Production Processes development can be achieved by:

- short-term goals, that include the reduction of waste through the reduction and recycling of valuable substances, by-products and residues with reduced both emissions and risks as a final outcome,

- medium-term goals, that include the development of an efficient production process, thus increasing the value of by-products,
- long-term goals, that include successive applications of organic production, thus developing "innovative products" (eg functional food), thus opening opportunities for new markets and meeting green productivity goals $[17,18]$.

\subsection{Sources and characterization of food waste}

Significant amounts of waste are generated annually in food production chains that are necessary to be exploited urgently [16]. The food industry produces significant amounts of waste which include: fruit and vegetables leftovers, discarded items, molasses and flakes from sugar refining, bones, blood and skin from meat and fish processing, leftovers from wineries, distilleries and breweries, waste from the dairy industry such as for example whey, wastewater from washing, blanching and cooling operations [19]. Most of the waste in the food industry is less hazardous waste because of its organic origin, however, it can also negatively affect on the quality of the environment. Waste in the food industry is generated in various sectors along the production chain, from farms, packaging / processing, transport / distribution, retail, service and households, with around $18 \%$ of waste estimated to come from food processing and packaging as a result of necessary operations. such as washing, peeling, seed removal, separation, etc. [16].

By exploiting the by-products of the food industry, the significance can be multiple. With adequate waste treatment, it can be used in the form of bioabsorbents, additives, new products that include functional food and bioactive ingredients, animal food, microorganism growth substrate, fertilizer materials after composting or as energy sources, for biofuel production (bio-hydrogen, biodiesel) $[8,17,20]$. Value-added products produced from waste in the food industry primarily include animal food, single-cell protein (SCP) and other fermented edible products such as bakery yeast, organic acids, amino acids, enzymes (lipases, amylases, cellulases), flavoring compounds, colorants, bacteriocins (from the culture of Lactobacillus lactis), microbial gums and polysaccharides [21]. According to Galanakis [15], food waste represents cheap source of important components, which, with adequate separation, can serve as functional additives.

One of the great challenges that contributes to increasing valorization and profitability is the search for new bioactive compounds and the usage of valuable nutritional and functional ingredients present in by-products such as: polysaccharides, vitamins, dietary fiber, bioactive components, etc. [8]. 
Through a detailed review of the literature, a large number of authors present the possibilities, feasibility and limitations that are based on the utilization of food waste, with the aim of transforming food waste into resources for the production of new products using eco-innovative approaches.

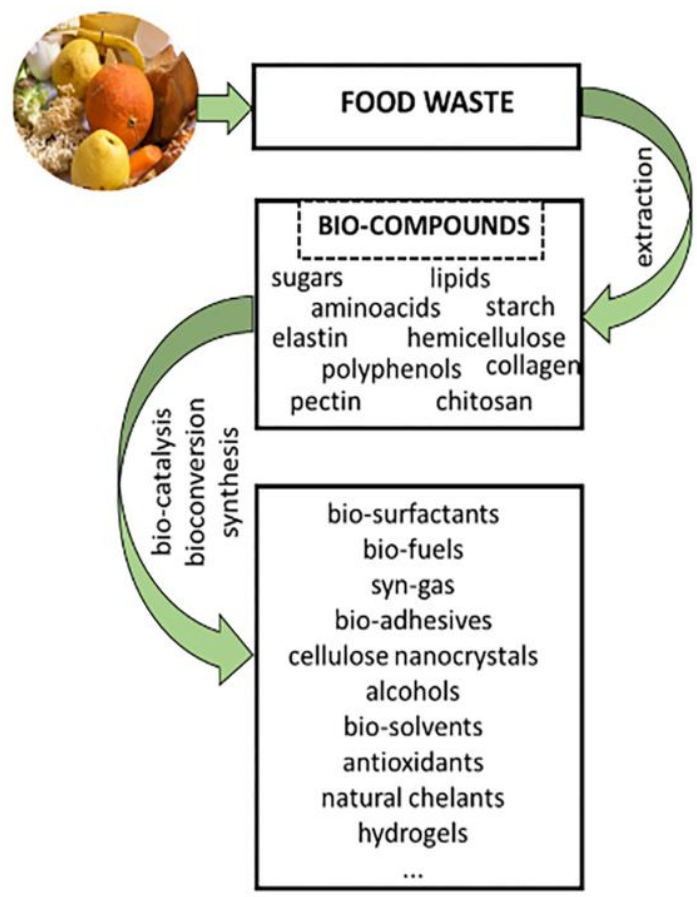

Figure 3 Bio-compounds present in the waste of food industry and some their potential valorisations and further applications (adapted from Lin et al. [22])

Slika 3. Bio-komponente prisutne u otpadu iz prehrambene industrije i neke od mogućnosti njihove valorizacije i dalje primene (prilagođeno iz Lin i saradnika [22])

\subsection{Utilization of multifunctional and high-value food ingredients obtained from waste of plant origin}

Large quantities of by-products of plant origin are produced every day, and their disposal in landfills has a very negative impact on the environment. In the food industry, large amounts of waste are generated from fruits and vegetables such as potato skins and apple skins [23], apple and grape pomace [24], from cereals such as rice bran [25], wheat bran and by-products from oat grinding [16], wastes such as e.g. residues of malt, hops, molasses from sugar beet production [23], residues of sunflower seeds [24] and soybean waste (okara) [26]. According to Kossev [17], waste from the fruit and vegetable processing industry, liquid dark colored waste juice from the industrial processing of olive oil, ie waste from the fermentation industries, contains large amounts of suspended matters, organic components and shows high values of biological (BOC or BPK on serbian) and chemical oxygen consumption (COC or HPK on serbian).

However, organic components of waste contain significant amounts of high-value molecules such as sugars, hemicellulose, cellulose, lignin, phenols, organic acids [17]. In addition to the usual procedures such as waste disposal, ie usage of waste as animal food or application for fertilization / composting, there is a need to minimize waste generation through better organization of the production process which will result in the creation of innovative and industrially important metabolites and products. Some examples of important metabolites from plant waste that can be used are: flavors (produced by bioconversion of waste material or solid-state fermentation), pectin and gelling agents, dietary fiber, (matrices for dyes, aromatic components and antioxidants, or their application in the industrial production of bread and beverages), effective and cheap bioadsorbents (which can be easily desorbed and biodegraded after use), produced enzymes, polysaccharides, organic acids, pigments, polyphenols, ethanol, which are described in more detail in Chapter 3 [17].

\section{UTILIZATION OF BY-PRODUCTS FROM WINE PRODUCTION FROM THE GRAPE POMACE}

Grapes represent one of the leading fruit crops in the world. In addition to the fact that grapes can be used in the production of certain food products such as juices, jams, jellies or can be used as raw, almost three quarters of the total annual production is used in the wine industry for wine production [27]., Between 7 and 8 liters of wine in average is received from $10 \mathrm{~kg}$ of grapes. When it comes to brandy, $10-15 \mathrm{~kg}$ of fruit is needed to get one liter, depending on the type of fruit, and even up to 20 $\mathrm{kg}$ is needed for raspberry brandy. However, the production of white and red wines generates significant amounts of solid organic waste such as pomace and grape stalks. Grape pomace (kom, drop or trop in Serbian) is a form of biomass which, together with other organic residues from wine production and residues from vineyards such as grape stalks, is considered a typical waste product [28].

Pomace is a dominant by-product from the wine industry that contains pulp residues, skin, 
seeds, stalks and comprises about $25 \%$ of the total mass of grapes processed in production [27,29,30], and is formed as a result of pressing and/or fermentation processes in the wine industry, while the quality and quantity of the produced pomace vary depending on the size of the winery and the applied technological procedure, as shown in Fig. 4 [28].

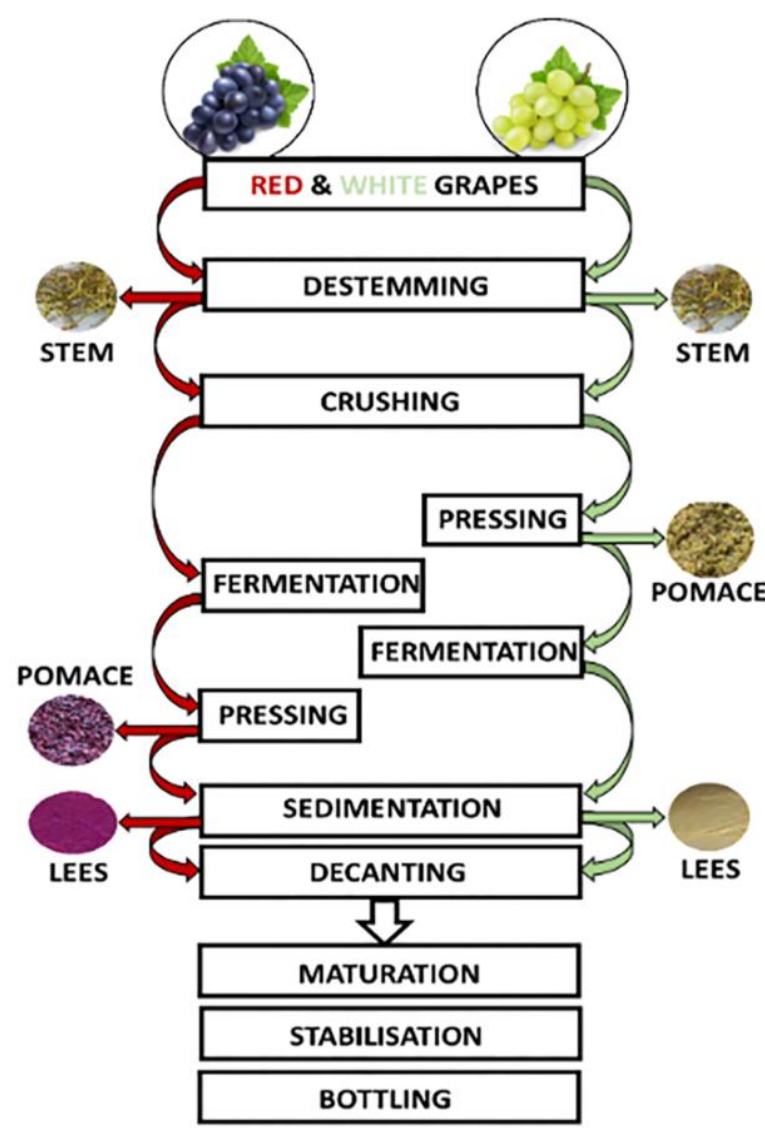

Figure 4. Scheme of generating grape and wine byproducts (stem, pomace, skin, seed and lees), during the production of red and white wines (adapted from Muhlack et al. [28])

Slika 4. Shema generisanja nus-proizvoda grožđa/vina (peteljka, komina, pokožica, semenka, talog), tokom proizvodnje crvenih I belih vina (prilagođeno iz Muhlack i saradnika [28])

In addition to the pomace, additional solid waste from the wine industry consists of sediments from clarification processes and sediment obtained after decantation, which are basically extinct yeasts [31]. In the production of red wine, grape juice (must) and pomace are fermented together, while in the production of white wines, must is separated from the pomace by pressing and only must is fermented [32].
Precisely because of these different production processes, white grape pomace contains more pulp and sugar residues [33].

According to the report by Hixson et al. [34], fresh white grape pomace has up to $38 \%$ glucose and fructose (expressed on dry weight), while red grape pomace after the production process contains about $1 \%$ glucose and fructose.

Although the pomace is most commonly used to make the pomace brandy, it is only one of the options for using the pomace, leaving a dry matter that can be used. Fruit growers and winegrowers, especially if they use their own fruit to make wine and brandy, should seriously consider other options for using the pomace. This also applies to those who buy fruit as a raw material, because the rest of the production can be used to make more products that can bring more profit.

Annually, millions of tons of pomace are generated which represents a great challenge for large wine companies and producers, considering the increasingly strict rules that apply to waste disposal [28].

In recent years, ecological awareness has been developed in developed wine-growing and wine-producing areas with the aim of protecting the environment, thus striving for the development of improved technologies for pomace treatment, and the pressure within the relevant sectors to implement plans based on adequate and sustainable disposal of this waste is increasing [28]. An example is Spain, where government gives wine companies three alternatives for pomace management: recycling, valorisation or disposal, with large fees being charged for pomace disposal, thus encouraging companies to use other more useful alternatives [31].

The potential use of by-products from grape processing is not only related to solving environmental problems, but also provides opportunities to improve food quality and develop high-value ingredients and products [35], as shown in Fig. 5.

Many studies indicate the possibility of using high - value products such as ethanol, organic acids (tartrates, malates), hydrocolloids, dietary fiber [24], sugars [28,34], phenolic components, antioxidants, [36-38] from the skin, as well as the usage of seed oil $[39,40]$, while the stalks contain high concentrations of tannins [41]. According to the tendency to use these natural compounds, possible applications of grape pomace are numerous, such as functional food, biosurfactants, cosmetics, pharmaceuticals and supplements $[32,42,43]$. 


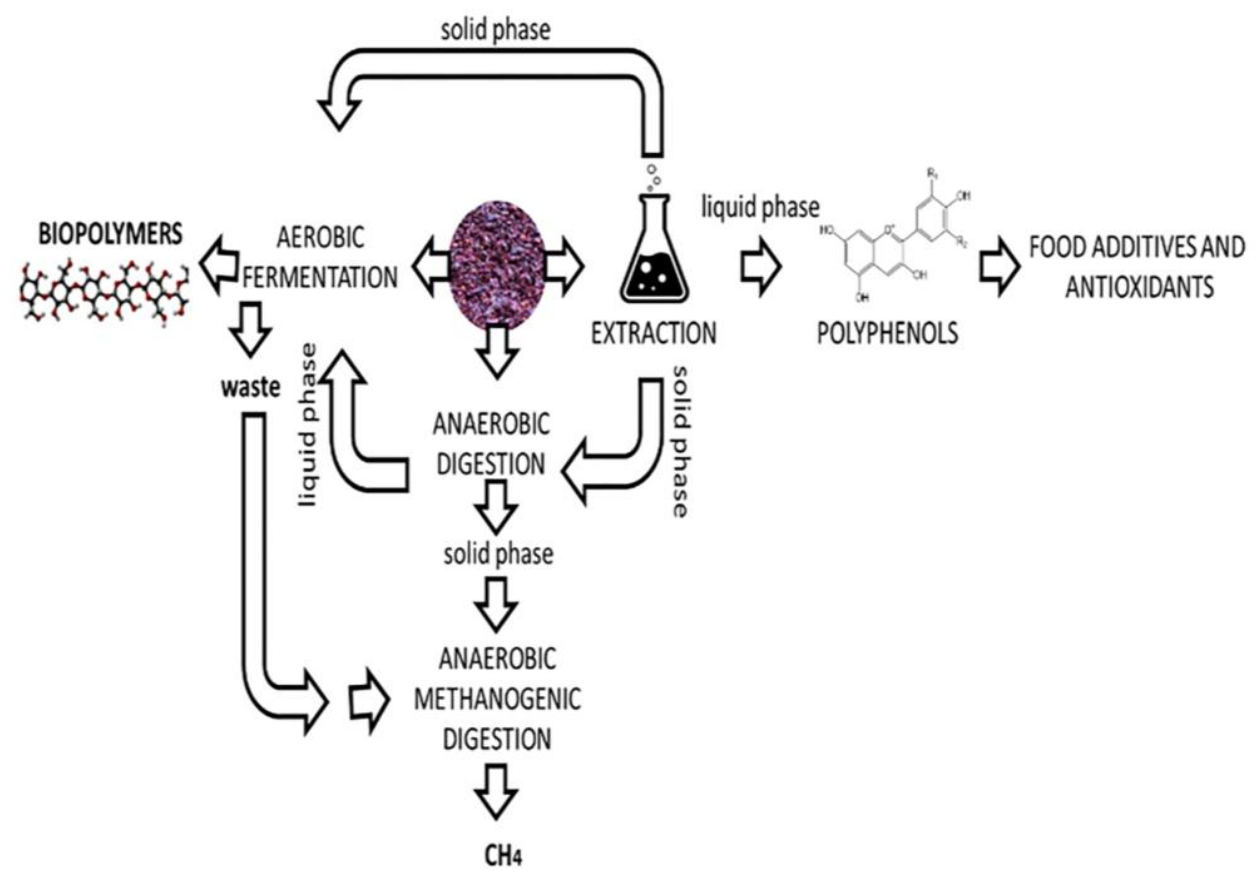

Figure 5. The scheme of obtaining polyphenols, biopolymers, and methane from the grape pomace (adapted from Martinez et al. [35])

Slika 5. Shema dobijana polifenola, biopolimera i metana iz komine grožđa (prilagođeno iz Martinez i saradnika [35])

Many studies indicate the possibility of using high - value products such as ethanol, organic acids (tartrates, malates), hydrocolloids, dietary fiber [24], sugars [28,34], phenolic components, antioxidants, [36-38] from the skin, as well as the usage of seed oil $[39,40]$, while the stalks contain high concentrations of tannins [41]. According to the tendency to use these natural compounds, possible applications of grape pomace are numerous, such as functional food, biosurfactants, cosmetics, pharmaceuticals and supplements $[32,42,43]$.

According to Rivera et al. [44] grape pomace can be used in the production of biosurfactants that have important applications in the food industry due to their emulsifying properties. However, due to the accumulation of large amounts of pomace which has a high moisture content, this by-product is prone to decay [45]. For these reasons, grape pomace should be processed immediately or converted into a stable dehydrated product [46], having in mind that the process of drying and storage of dried material over a long period of time leads to significant losses of essential components, especially phenolic compounds [47]. It should be also considered that even after certain treatments, such as extraction of high-value components from pomace, tartrate or ethanol, streams of solid residues remain, which must subsequently be adequately removed to prevent groundwater pollution and the spread of unpleasant odors [28].

Also, pomace and other residues from the wine industry can be recycled as compost [48-50] or used as livestock food [32].

\section{Pomace as an organic fertilizer}

Pomace can be an excellent organic fertilizer, although it is not the richest in terms of nutrients that are present in it. In addition, it is excellent for improving soil structure. Although there is a practice of leaving the pomace in the ground for the purpose of fertilization, composting has multiple advantages, primarily due to the mineral enrichment of the fertilizer.

Making compost from pomace also includes adding other crop residues. This certainly includes withered leaves and pruning residues. Sawdust, hay and straw are also recommended, and the remains that are infected should be burned as a precaution. 
The goal of adding other plant residues is to raise the levels of NPK (nitrogen, phosphorus and potassium) which are not present in high concentration in pomace. However, there is a significant difference between different types of fruit and pomace from wine and brandy. For example, white grape pomace has a much higher concentration of nitrogen and sugar than red grape pomace from the standard wine production process. The reason for that is that the red grape pomace is left to ferment together with the fruit juice, while that is not the case with white grapes and white wine production.

When making compost, special attention should be paid to the looseness of the material to be composted. Considering the physicalmechanical properties of the pomace, it is necessary to add substances that will make the mixture more loose and thus provide needed oxygen for the bacteria. One of the possibilities is to dry the pomace in order to remove excess moisture before composting. Pomace can be mixed with manure and left to burn. In this case, microorganisms from the manure decompose the remnants of fruit production.
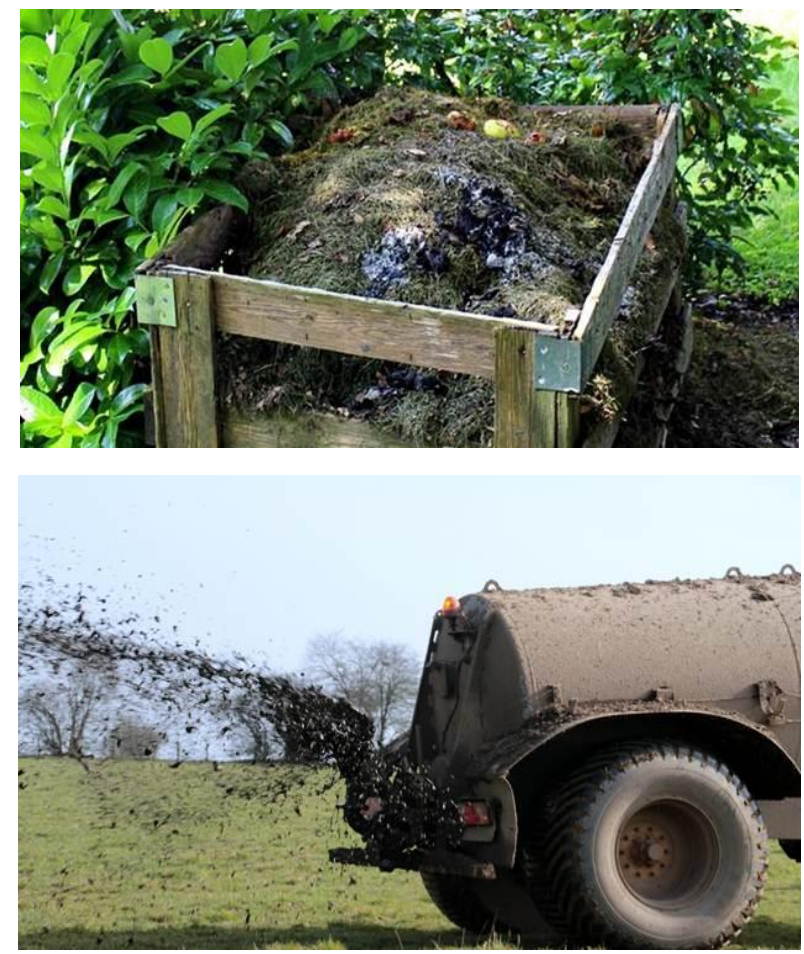

Figure 6. Compost made from the pomace Slika 6. Kompost od komine

Composting waste from the wine industry, however, is an alternative to traditional waste disposal [49].

\section{Pomace as feed}

Fruit pomace/pulp rich in cellulose, such as apples, has long been used as livestock food. In the last few years, it has been recommended to feed cattle with grape pomace. One of the reasons for that is the explosion of production in winemaking, which results in a large amount of waste material.

All pomace, in addition to cellulose, is rich in sugars, organic acids, tannins, vitamins, antioxidants and other substances present in fruit. But it should not be forgotten that fermentation yeast can also be found in pomace, especially in the pomace that remains from the production of red wine.

Yeast-containing pomace also contains Bcomplex vitamins. In combination with other livestock food, an excellent food for fattening cattle is obtained. The reason for this is that yeast, and especially B-complex vitamins, increase the appetite of animals, as well as humans in general. The presence of stones in pomace is also beneficial for animals, especially grape seeds. Of course, it can be combined with other livestock food.

When it comes to the use of pomace as livestock food, the results of scientific research are twofold. While some studies show the positive properties of pomace as a source of condensed tannins that lower the level of methane produced inside animal organisms, other studies suggest that the inclusion of pomace in livestock food may lead to reduction of digestibility.

\subsection{Utilization of energy from grape pomace} obtained by applying the thermal conversion process

By applying thermal conversion, highly valuable products such as energy (in the form of heat or electricity), coal, transport fuels that have economic significance can be obtained from pomace [51].

Grape pomace can also be used as a significant bioenergy source [52] and for this purpose, several thermochemical processes that allow conversion have been developed, but a number of technical and economic issues arise. Additional factors that can have a major impact are: seasonal availability of biomass, transport and storage logistics, conversion efficiency, and the value of conversion products [53,54] (Fig. 7).

Relevant properties of fuels obtained by conversion from pomace include calorific value (key parameter related to the performance of thermochemical conversion, which refers to the energy content of the raw material), alkaline ratio, fixed carbon to volatile matter ratio, ash composition and moisture content [28]. 


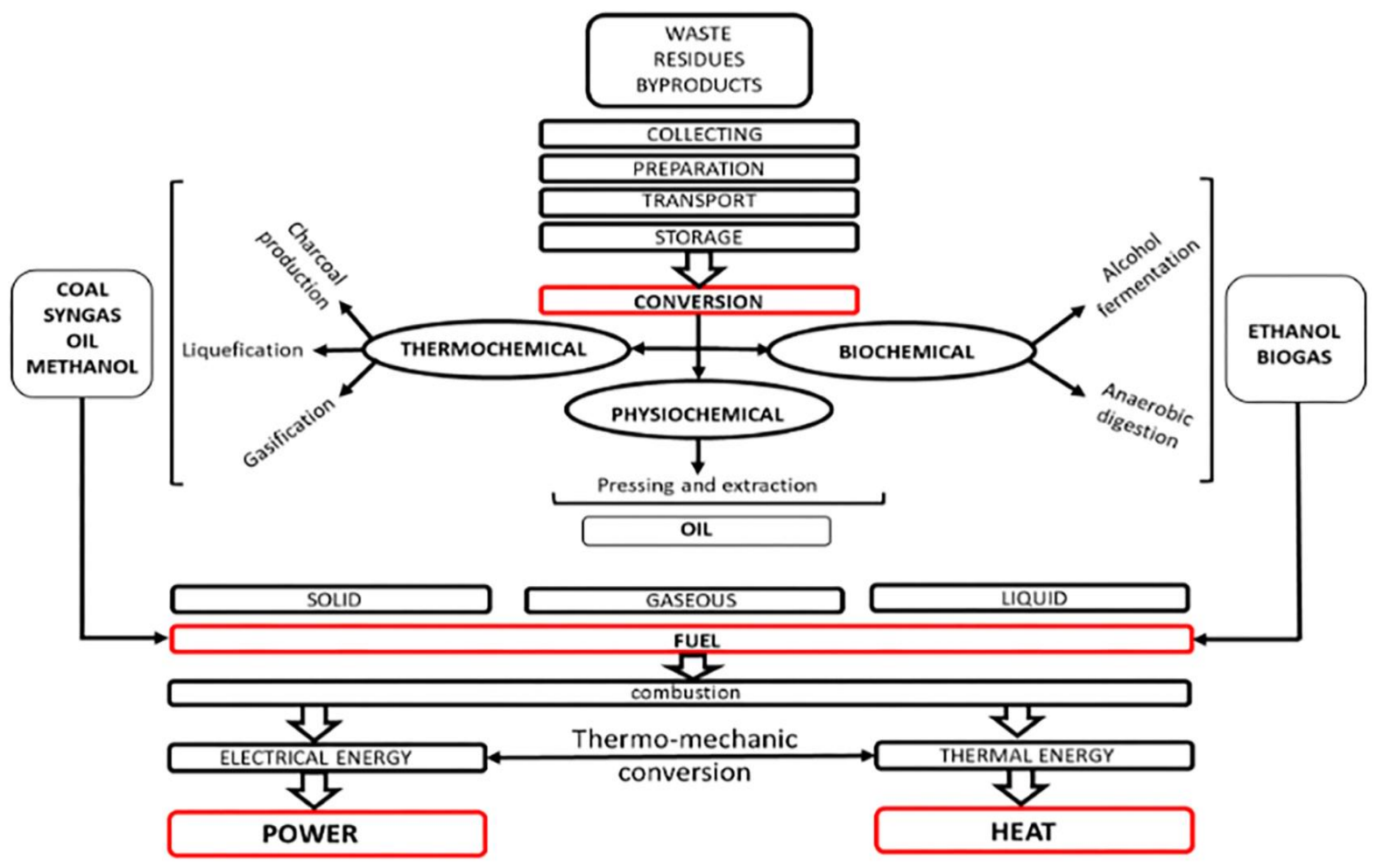

Figure 7. Overview of renewable energy production from organic substrates for example, such as grape pomace (adapted from [54,55])

Slika 7. Pregled proizvodnje obnovljive energije iz organskih supstrata na primer, kao što je komina (prilagođeno iz [54,55])

The calorific values of these fuels are similar to the calorific values of fuels obtained by the conversion of other agricultural and industrial residues (sawdust) [55-58], but also to the calorific values of coal [59]. Biomass with high concentrations of alkali metals, as is the case with grape pomace, is very prone to ash agglomeration and requires an adequate strategy that will ensure the effective conduct of large-scale processes [60]. The moisture content of the raw material is also a very important parameter, because if the raw material is wet, it can negatively affect the energy balance and economic efficiency of thermal conversion of biomass into energy, so water removal is required prior the process [61]. Due to the high moisture content, thermal treatment of pomace by torefection (thermal pretreatment involving heating the biomass to a temperature of $200-300^{\circ} \mathrm{C}$, in an inert gaseous environment) [55,62], hydrothermal carbonization [63], or using solar drying [28] is necessary. Torefaction can be classified depending on the heating temperature as light $\left(200-235^{\circ} \mathrm{C}\right)$, mild $\left(235-275^{\circ} \mathrm{C}\right)$ and severe $\left(275-300^{\circ} \mathrm{C}\right)$ [62]. The effect of torefection is reflected through the reduction of moisture, which increases the calorific value by reducing the ratio of oxygen:carbon and hydrogen:carbon biomass [55]. Hydrothermal carbonization is a process similar to torefection that involves low-temperature heating of biomass at temperatures of $180-250^{\circ} \mathrm{C}$ [28]. Heating takes place in an aqueous suspension at saturated pressures, making this process ideal for the treatment of highly moist biomass such as grape pomace [63]. The application of hydrothermal carbonization removes most of the non-organic ingredients (alkaline salts) that dissolve in the process water, which significantly reduces the ash content [28].

It is very important to point out that "second generation" biofuels, obtained from waste biomass, are easily converted into energy, thus avoiding the environmental, economic and social impacts associated with production [51]. However, despite numerous studies based on the usage of grape pomace for various applications, it has not been successfully implemented and applied on a larger scale [29].

\subsubsection{Combustion, gasification and pyrolysis}

There are several technologies available that perform thermal conversion of previously prepared biomass (dry pomace), namely: combustion, gasification and pyrolysis [28]. Depending on the applied technological process, heat and electricity can be produced, ie biofuels such as syngas, coal and biofuels. Syngas and biofuels can be used with additional refining to produce transport fuels such as diesel or high octane gasoline [64-67]. The heat 
energy released during biomass combustion can be used to heat a process or a space [68], or it can be used to produce electricity through a steam turbine and generator $[69,70]$. The usage of grape pomace pellets for heat production is a promising technology from an environmental perspective, given that the main advantage over fossil fuels lies in the reduced contribution to climate change [71]. According to Miranda et al. [57] grape pomace pellets can be used in combustion processes because they show good thermal characteristics, but undesirable values of certain parameters such as ash level and emissions of organic and nonorganic pollutants have also been shown. However, it was found that the combination of pomace pellets and oak sawdust (lat. Quercus pyrenaica) improves these undesirable parameters without deteriorating the thermal properties.

Studying the combustion characteristics of agricultural and industrial residues, including raw grape pomace, Fernandez et al. [72], suggests that combustion of the pomace in the range of $550^{\circ} \mathrm{C}$ to $950^{\circ} \mathrm{C}$ forms fine particles that pose an environmental risk, while TG and DTG studies have shown that after combustion of the pomace almost $10 \%$ of the mass remains as ash.

Gasification is a process of partial oxidation of combustible biomass at high temperatures (800$1000^{\circ} \mathrm{C}$ ), in order to form low-calorific flammable gas mixtures (SynGas), as well as ash [28,53,73]. Syngas mainly contains carbon monoxide, hydrogen, methane and carbon dioxide [74], while the components of the exhaust flue gas include nitrogen, water vapor, hydrocarbons [28]. Syngas can be used to generate heat and electricity [58], or by purification it can be used to produce hydrogen gas or liquid transport fuels $[65,74]$. One of the potential ways to use grape pomace is to transform it into a syngas by gasification process [55]. According to Lapuerta et al. [59], it was concluded that grape pomace is less efficient for the gasification process compared to other analysed agricultural and wood residues, while cogasification studies with coal coke showed improved syngas quality when biomass was used. According to Hernandez et al. [58], grapes pomace and other analysed raw materials showed higher quality of produced gas and higher efficiency of gasification compared to coke.

Pyrolysis is the thermal decomposition of biomass under limited conditions at a temperature of about $400-700^{\circ} \mathrm{C}[53,75]$ The simplest process of thermochemical conversion of biomass results in a mixture of gases, liquid (tar or bio-oil) and coal $[49,67]$. According to Arvanitoyannis et al. [47], pyrolysis of wine waste produces fixed carbon, volatile substances, ash, or gases: $\mathrm{H}_{2}, \mathrm{CH}_{4}, \mathrm{CO}$, $\mathrm{CO}_{2}$. Increasing the pyrolysis temperature of wine waste affects on the increased content of fixed carbon and ash, while the content of volatile substances decreases [49,67]. Bio-oils contain a number of organic compounds including aromatic hydrocarbons, alkanes, phenols, ethers, alcohols [75] and can be used as a raw material for the production of heat and electricity. Coal produced from wine waste at temperatures of $600-700^{\circ} \mathrm{C}$ is suitable for the production of fuel briquettes, while the naturally porous structure of grape pomace coal can be further improved by gasification with the aim of producing activated carbon that can be used as an adsorbent [49].

\subsection{Utilization and extraction of significant high-} value ingredients from grape pomace

By-products of plant origin are a significant source of bioactive compounds [24,76], that can be used as natural antioxidants and important ingredients of functional foods [24]. However, most by-products are not currently exploited as a source of bioactive components [76].

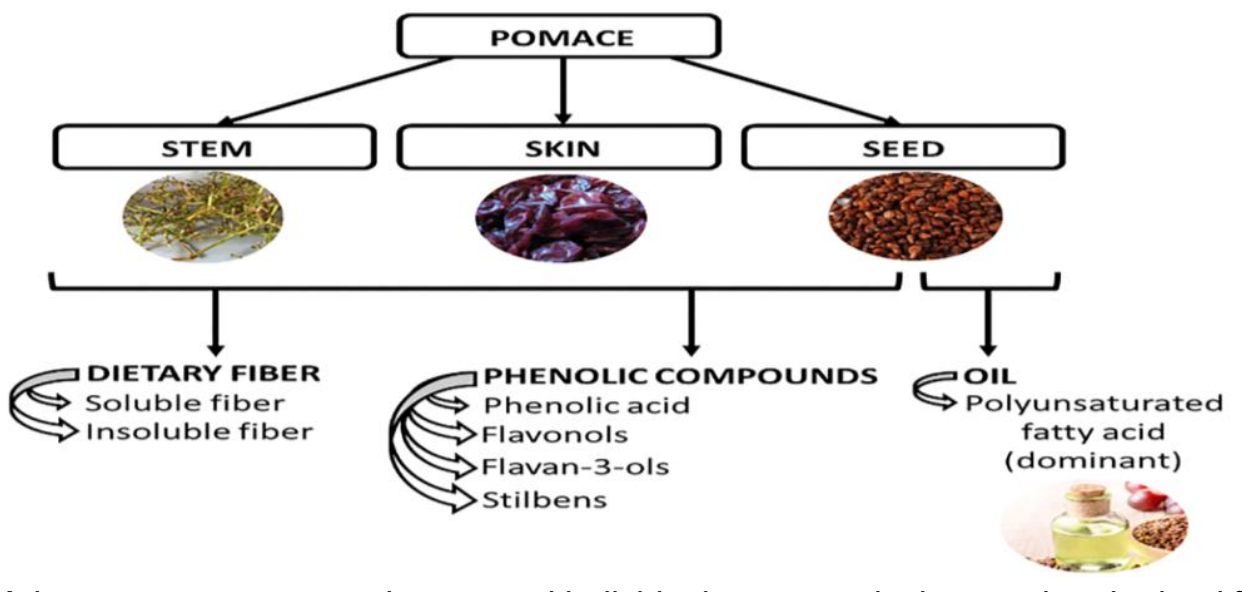

Figure 8. Main grape pomace constituents and individual compounds that can be obtained from them (adapted from Beres et al., 2017 [27])

Slika 8. Glavni konstituenti komine grožđa i pojedine komponente koje mogu biti dobijene iz njih (prilagođeno iz Beres i saradnika, 2017 [27]) 
Grapes contain significant amounts of various compounds that are partially extracted during wine production [28], but the residual pomace (skin, seeds) represents a good source of high-value components (Fig. 8), such as polyphenols [27,76], pigments, antioxidants [28], dietary fiber [27], sugars, fatty acids [77-79], lignocellulosic material, tartaric acid [28].

Therefore, many studies dealing with byproducts from the wine industry are based on the extraction, characterization and utilization of these compounds [27,76,80-83].

\subsubsection{Utilization and application of polyphenolic} compounds from wine industry by-products

Phenols are defined as secondary metabolites of plants that have one or more aromatic rings substituted with one or more hydroxyl groups within their structure $[28,84]$. They are usually classified according to their chemical structure and molecular weight into simple phenols $\left(\mathrm{C}_{6}-\mathrm{C}_{1}\right.$ and $\left.\mathrm{C}_{6}-\mathrm{C}_{3}\right)$, flavonoids $\left(\mathrm{C}_{6}-\mathrm{C}_{3}-\mathrm{C}_{6}\right)$, polymeric compounds (hydrolyzable and condensed tannins, lignin) and other groups of phenols of different structures such as xanthanes, stilbenes, betacyanins, etc. [85]. The skin from the grape pomace is a rich source of phenolic acids such as hydrocinnamic, fertaric acid, or esters of kaftaric and kutaric acid, while the seeds mainly contain gallic and protocatechuic acid [82-86]. In red grape pomace, anthocyanins (malvidin-3-O-glucoside, peonidin-3-glucoside, petunidin-3-glucoside), flavonols, and flavan-3 are the most dominant flavonoids, while others are present in smaller amounts [83-87].

In recent years, a number of extraction techniques have been developed, including pressurised liquid extraction [37,88-90], supercritical $\mathrm{CO}_{2}$ extraction $[38,89]$, or ultrasonic extraction [79] and microwave extraction [91-95] or extraction by using a pulsating electric field [91], which can be used to extract bioactive components, primarily polyphenols from wine byproducts. In general, the most distinctive are supercritical $\mathrm{CO}_{2}$ extraction, as the most efficient for non-polar compounds such as carotenoids, and pressurised liquid extraction that can be used for extraction of more polar compounds such as polyphenols [24]. Supercritical $\mathrm{CO}_{2}$ extraction is a new technique for extracting analytes of interest from a solid matrix, which has a number of advantages: it is non-toxic, non-flammable, nonpolluting, cheap and there are no traces of residual solvent in the extracted product [92]. Fluid can be considered supercritical when heated above the critical temperature and when it is under pressure above the critical pressure, whereby due to temperature and /or pressure manipulation within the critical range, the physical extraction properties can be modulated, adjusting the solvent selectivity for each target compound [41]. Pressurised liquid extraction exploits the differential properties of conventional solvents at elevated temperatures and high pressures, affecting the solvents, sample, and interactions between them by improving the extraction of organic analytes from solid samples with the selected solvent [41].

Phenolic components show significant antiallergic, anti-inflammatory, antimicrobial, cardioprotective and anticancer effects [41]. In vitro and in vivo studies show that flavonoids present in wine byproducts act as effective accumulator of free radicals, and as a result they act as powerful antioxidants and metal chelators [95]. Because of this, wine pomace products are mainly used to enrich food with antioxidants [83]. Grape polyphenols can be used as natural components to prevent oxidation and as functional ingredients of healthy food [96-98]. According to Ferreira et al. [97] grape pomace extract incorporated into edible chitosan films has an improved effect on antioxidant properties and prolongs shelf life, while according to Garcia-Lomilloi González-San Jose [83], pomace can be applied in food industry through the development of spices that have an antioxidant and antimicrobial role.

Due to the high concentrations of bioactive compounds in the obtained grape pomace extracts, very small amounts of these extracts are required for successful application in food systems (Tab. 1).

Extracted anthocyanins from pomace in the form of a commercial product "enocyanin", which has excellent properties for coloring food products, have found application in various matrices such as dairy desserts, ice creams, beverages, juices and other products $[24,83]$. However, in addition to all the above possibilities of using phenolic compounds, it should be taken into account that during food processing phenolic compounds can be degraded, especially during processes where high temperature is applied [99]. Based on the previously presented facts, several categories of food that can be successfully enriched with phenols from wine pomace are presented (Tab. 1).

There are major global brands that claim to use polyphenols, mainly resveratrol from grapes, such as: "100 Natural", "Nature's Way", "Maximum Strength", "GrapeSeedRich". These products confirm the potential of bioactive compounds extracted from grapes and grape by-products [27].

According to $\mathrm{Xu}$ et al. [100], the use of pomace extract reduces the formation of acrylamide during Mylard reactions, indicating another possibility of using waste wine pomace. 
Table 1. Food products enriched/fortified with powder, flour or extracts of grape by-products (whole pomace, skin and seed), which known as source of highly valuable compounds (selection from Reference [83])

Tabela 1. Prehrambeni proizvodi obogaćeni prahom, brašnom ili ekstraktom iz nus-proizvoda prerade grožđa (cela komina, pokožica i semenka), koji u poznati kao izvor visoko vrednih komponenti (izdvojeno iz literature [83])

\begin{tabular}{|c|c|c|c|c|}
\hline \multirow{2}{*}{$\begin{array}{l}\text { Food products } \\
\text { (cereals and dairy } \\
\text { products) }\end{array}$} & \multicolumn{2}{|c|}{$\begin{array}{l}\text { Grape by-products (pomace) and its constituents } \\
\text { (seed and skin) }\end{array}$} & \multirow{2}{*}{$\begin{array}{c}\text { Aim of } \\
\text { study/improvements }\end{array}$} & \multirow{2}{*}{ Reference } \\
\hline & $\begin{array}{l}\text { Products fortified } \\
\text { with }\end{array}$ & Source of bio-compounds & & \\
\hline Breads and dough & Grape seed flour & Phenolic compounds & $\begin{array}{l}\text { Physical, sensory and } \\
\text { textural properties }\end{array}$ & {$[104]$} \\
\hline Breads and dough & Grape seed powder & $\begin{array}{l}\text { Phenolic compounds; dietary } \\
\text { fiber; fat }\end{array}$ & $\begin{array}{l}\text { Physiochemical and } \\
\text { rheological properties }\end{array}$ & [105] \\
\hline Bread & Grape seed & $\begin{array}{l}\text { Phenolic compounds } \\
\text { (especially gallic acid and } \\
\text { catechin) }\end{array}$ & $\begin{array}{l}\text { Physical and antioxidant } \\
\text { properties }\end{array}$ & [106] \\
\hline White bread & Grape pomace & Polyphenols and dietary fiber & $\begin{array}{l}\text { Physichemical, } \\
\text { antioxidants, nutritional } \\
\text { and sensory properties }\end{array}$ & [107] \\
\hline Rye bread & Grape by-products & $\begin{array}{l}\text { Soluble and insoluble dietary } \\
\text { fibre; phenolic compounds }\end{array}$ & $\begin{array}{l}\text { Antioxidant, rheological } \\
\text { and sensory properties }\end{array}$ & [108] \\
\hline Wheat biscuits & White grape pomace & $\begin{array}{l}\text { Phenolic compounds and } \\
\text { dietary fibre }\end{array}$ & $\begin{array}{l}\text { Rheological, nutraceutical, } \\
\text { physical and sensory } \\
\text { properties }\end{array}$ & [109] \\
\hline Biscuit/cookies & $\begin{array}{l}\text { Defatted grape seed } \\
\text { powder }\end{array}$ & Phenolic compounds & $\begin{array}{l}\text { Physicochemical, } \\
\text { antioxidant and sensory } \\
\text { properties }\end{array}$ & [110] \\
\hline Muffins & $\begin{array}{l}\text { Lyophilized grape } \\
\text { by-products (skin } \\
\text { powder) }\end{array}$ & Phenolic compounds & $\begin{array}{l}\text { Nutritional value, sensory } \\
\text { properties and reduce } \\
\text { formation of } \mathrm{CML}\end{array}$ & [111] \\
\hline $\begin{array}{l}\text { „breakfast extruded } \\
\text { cereals“ }\end{array}$ & $\begin{array}{l}\text { Grape peel and } \\
\text { seed flour }\end{array}$ & $\begin{array}{l}\text { Phenolic compounds and } \\
\text { dietary fibres }\end{array}$ & $\begin{array}{l}\text { Chemical and physical } \\
\text { characterization, sensory } \\
\text { properties }\end{array}$ & [112] \\
\hline $\begin{array}{l}\text { Breads, muffins, } \\
\text { brownies }\end{array}$ & $\begin{array}{l}\text { Red and white grape } \\
\text { pomace }\end{array}$ & $\begin{array}{l}\text { Phenolic compounds and } \\
\text { dietary fibres }\end{array}$ & $\begin{array}{l}\text { Physicochemical, } \\
\text { nutritional, antioxidant and } \\
\text { sensory properties }\end{array}$ & [113] \\
\hline $\begin{array}{l}\text { Cereal bars, } \\
\text { pancakes and } \\
\text { noodles }\end{array}$ & Grape seed flour & Phenolic compounds & Antioxidants properties & [114] \\
\hline $\begin{array}{l}\text { Fermented milk } \\
\text { (novel functional } \\
\text { product) }\end{array}$ & $\begin{array}{l}\text { Phenolic extract } \\
\text { from grape pomace }\end{array}$ & Phenolic compounds & $\begin{array}{l}\text { Antioxidant and sensory } \\
\text { properties }\end{array}$ & [115] \\
\hline $\begin{array}{l}\text { Full-fat and non-fat } \\
\text { yoghurts }\end{array}$ & Grape seed extracts & Phenolic compounds & $\begin{array}{l}\text { Antiradical and antioxidant } \\
\text { activity }\end{array}$ & [116] \\
\hline Yogurt & Grape skin flours & $\begin{array}{l}\text { Phenolic compounds and } \\
\text { fibres }\end{array}$ & $\begin{array}{l}\text { Physicochemical, } \\
\text { microbiological and } \\
\text { sensory properties }\end{array}$ & [117] \\
\hline $\begin{array}{l}\text { Yogurt and salad } \\
\text { dressing }\end{array}$ & $\begin{array}{l}\text { Dries whole pomace } \\
\text { powder }\end{array}$ & $\begin{array}{l}\text { Phenolic compounds and } \\
\text { dietary fibre }\end{array}$ & $\begin{array}{l}\text { Nutritional value and } \\
\text { improving storability }\end{array}$ & [118] \\
\hline $\begin{array}{l}\text { Semi-hard and hard } \\
\text { cheeses }\end{array}$ & $\begin{array}{l}\text { Grape pomace } \\
\text { powder }\end{array}$ & Phenolic compounds & $\begin{array}{l}\text { Physicochemical, } \\
\text { nutritional and antioxidant } \\
\text { properties }\end{array}$ & [119] \\
\hline
\end{tabular}

Grape pomace extracts can also be successfully used in food preservation as an effective antibacterial agent against various bacterial genera. According to Xu et al. [101], the examined grape pomace extracts showed antibacterial activity against Listeria monocytogenes and Staphylococcus aureus, while according to García-Lomillo et al. [45], extracts of the seedless part of the pomace show antibacterial activity against total aerobic mesophilic bacteria, lactic acid bacteria and Enterobacteriaceae. According to Silvan et al. [102], grape seed extract shows antibacterial activity against Campylobacter spp., with phenolic acids and catechins being responsible for the inhibitory effect of the extract. Grape pomace extracts are also used in cosmetics. 
According to research conducted by Wittenaueretal [103], the effectiveness of grape pomace as an inhibitor of the activity of proteolytic enzymes such as collagenase and elastase, related to skin aging has been tested. The best results of enzyme inhibition have been obtained with hydrophilic polyphenols such as phenolic acids, especially gallic acid.

There are commercialized cosmetic products with grape polyphenols, such as day and night creams "Pure Super Grape" (Marks and Spencer United Kingdom), anti-wrinkle cream and protective cream "Caudalí" (France) with the belief that they use polyphenols from grape seeds [27].

3.2.2. Utilization and application of dietary fibers from by-products of the wine industry

Dietary fibers are defined as "carbohydrate polymers with ten or more monomer units, which are not hydrolyzed by endogenous enzymes in the human small intestine" [120]. The main effect associated with the consumption of dietary fiber is to reduce the risk of cardiovascular disease, diabetes, to improve transport through the digestive tract, to reduce cholesterol and obesity, and protection against cancer [27].

The monosaccharide composition of grapes is diverse and consists mainly of rhamnose, arabinose, xylose, mannose, galactose, glucose, uronic acids (mainly galacturonic acid) [41,121]. Grape skin contains a large amount of homogalacturonan and small amounts of pectin polysaccharides (ramnogalacturonan $I$ and ramnogalacturonan II) [121]. Pectins with a low degree of methyl esterification are the main polymer components of the grape pomace cell wall, while cellulose is the dominant polysaccharide of the stem cell wall [121]. According to Kim et al. [122], grape seeds do not only contain oil and phenolic components, but also contain about $40 \%$ of fiber. Pectin is a highly valuable ingredient in functional food widely used for its gelling ability and as a stabilizing agent [27].

Dietary fiber extraction can be performed in several ways: conventional solvent extraction, microwave and ultrasonic extraction, or enzymatic extraction method [123]. For the extraction of sugar and polysaccharides (soluble fibers) from dried grounded pomace (different particle sizes), grapes of the Pinot Noir variety, according to Beres et al. [41], hot water (different temperatures) was used, with the application of different substance:solvent ratio. According to Minjares-Fuentes et al. [124], ultrasonic extraction has been used for extraction of pectin from pomace with citric acid as an extraction agent, the obtained results suggesting that this type of extraction may be a good option for industrial application. Recently, enzyme extraction has attracted much attention due to the need for ecological extraction methods, however, the application of enzyme treatment or pretreatment can affect the cell wall structure of grape pomace, breaking the glycosidic bonds of polysaccharide chains to mono- and oligosaccharides [36].

Dietary fiber of grape pomace has the potential to be used in various food products such as bakery products, beverages, meat products, and can be used in cosmetics and the pharmaceutical industry as well $[27,125]$. Numerous studies have been conducted with the aim of using pomace and its fractions in various food products such as bread [105,108], biscuits [108], muffins [113] or even yoghurt [118], enriching them with valuable fibers (Tab. 1).

Grape pomace skin is a good source of lignin, cellulose and hemicellulose, so it has great potential as an environmentally friendly material [123]. The extremely high content of soluble sugars in white grape pomace can be used to form innovative biodegradable packaging materials with excellent flexible properties [125].

\subsubsection{Obtaining tartaric acid from by-products of} the wine industry

One of the alternatives for valorization of oenological waste, pomace and sediment is through the production and utilization of tartaric acid [31,126-130]. Tartaric acid is a significant product obtained from wine pomace that has found application in various sectors dealing with food, due to its antioxidant, preservative properties, i.e. $\mathrm{pH}$ regulatory properties [83].

Flow diagram of the technology of obtaining tartaric acid from wine lees, recommended by Rivas et al. [129], is shown in Fig. 9.

Utilization of tartaric acid from wine lees and grape pomace involves extraction with dilute acid or warm water [127], precipitation of tartrate with calcium salts [128] and finally conversion of calcium tartrate to tartaric acid with sulfuric acid [28]. According to Versari et al. [128], analysing the recovery of tartaric acid from three different wine wastes, at three different $\mathrm{pH}$ values of the medium $(5.2 ; 6.5 ; 9.0)$ with the addition of different amounts of calcium chloride $\left(7.6 ; 11.4 ; 15.2 \mathrm{~g} / \mathrm{dm}^{3}\right)$, it was concluded that the utilization of tartaric acid is maximal at low $\mathrm{pH}$ (5.2) and with the addition of larger amounts of calcium chloride $\left(15.2 \mathrm{~g} / \mathrm{dm}^{3}\right)$. According to research [127], it was concluded that extraction with warm water gives a higher utilization of tartaric acid per $\mathrm{kg}$ of grape pomace. More recently, a study conducted by Kontogiannopoulos et al. [126], clearly showed that the utilization of 
tartaric acid from wine lees can be achieved by using a cationic ion-exchange resin under mild conditions (ambient temperature), thus achieving the utilization of tartaric acid of $75 \%$ and also avoiding the formation of calcium sulfate sediment from the conventional process. According to Braga et al. [131], between 50-75 g of tartaric acid can be obtained from one kilogram of wine pomace or between 100-150 g of tartaric acid from one kilogram of wine lees.

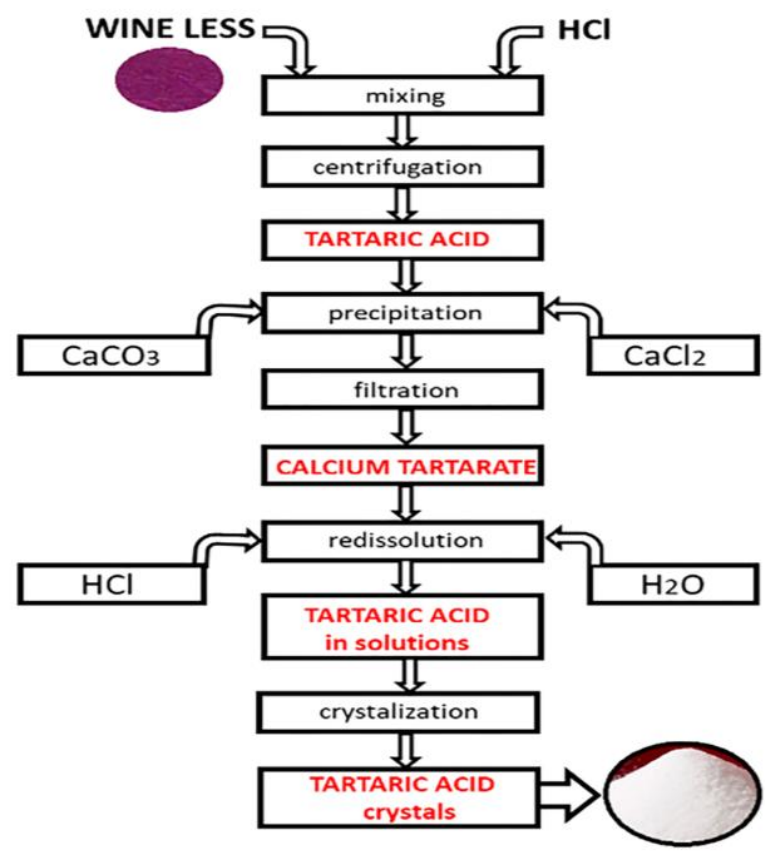

Figure 9. Flow technology diagram of production of tartaric acid from a wine precipitate/less (adapted from [129])

Slika 9. Dijagram toka tehnologije dobijanja vinske kiseline iz vinskog taloga (prilagođeno iz [129])

\subsubsection{Utilization and application of grape seed oil}

Grape seeds are roughly composed of about $40 \%$ fiber, $10-20 \%$ lipids, $10 \%$ protein, as well as other constituents, such as complex polyphenols, sugars, minerals, etc. [132]. Grape seed oil is widely recognized as a source of unsaturated fatty acids and polyphenolic components [77], and even after the extraction of oil from seeds there remains unused polyphenolic compounds [133], mostly in seeds - about $70 \%, 20 \%$ in the skin and about $10 \%$ in pulps [43].

Since the production of oil by the classical mechanical pressing process does not give a high yield, as well as the extraction with solvents such as hexane is doubtful due to its potential environmental toxicity [134], as well as residue issues, new extraction procedures are subject of research. Some of the promising extraction techniques suitable for oils are supercritical fluid extraction (SFE) [135-137], as well as ultrasoundassisted extraction (UAE) [138].

The bioactive components of the oil, such as phytosterols, tocopherols, tocotrienols, flavonoids, phenolic acids and carotenoids, enable the widespread use of oils in both the pharmaceutical and food industries, especially given the trend of replacing animal ingredients with plants [27].

Taking into account the growing market demand for functional foods, one of the interesting applications is the replacement of some fats and saturated fatty acids of meat with unsaturated fatty acids from grape seed oil, which reduces caloric value, lowers cholesterol and improves certain sensory properties [139]. Grape seed oil has the potential as a raw material for biodiesel production. When obtaining biodiesel from vegetable oils, an important parameter is the composition of fatty acids, where monounsaturated fatty acids are preferred over polyunsaturated [27]. Conversely, oils with polyunsaturated fatty acids are more valuable in the pharmaceutical industry due to their antioxidant properties. Grape seed oil can also be used here due to bioactive components such as phytosterols and squalene, which coincides with the growing market demand for natural products without the addition of synthetic additives [140].

\subsection{Application of biological treatments for obtaining high-value products from grape pomace}

When it is talked about the application of biological treatments for obtaining products from grape pomace, it is mainly ment fermentation. Grape pomace is traditionally used in many European countries as a raw material for obtaining strong alcoholic beverages(spirits), which is justified due to the large amounts of residual sugar, both in soluble and insoluble forms. According to Corbin et al. [141], 31-54\% w/w of grape pomace, calculated on the dry mass, consists of carbohydrates, of which $47-80 \%$ are soluble in aqueous media, while residues that are not soluble in ethanol mainly consist of polyphenols, pectin polysaccharides, heteroxylanes and cellulose. Problems that can occur with producers who use grape pomace as a raw material for spirits are unwanted microbiological processes that mainly occur due to inadequate storage conditions of the pomace, which affects on the undesirable properties of the quality of spirits [142]. All this can be solved by appropriate storage of the pomace until processing and by modeling of fermentation and distillation [143,144]. 


\subsubsection{Bioethanol and biogas}

Due to its high cellulose content, grape pomace is an excellent raw material for obtaining bioethanol and biogas, and at the same time the issue of waste from the wine industry is solved, which is very important from an ecological point of view. Also, there are no ethical disagreements in the use of industrial waste, as there is in the use of conventional crops, where primary purpose is human and animal nutrition [145].

Studies have shown that the pomace of white grape varieties [33], as well as white and black varieties [141] can serve as an excellent material for bioethanol production.

In addition to obtaining bioethanol, grape pomace can also be used as a raw material for obtaining biogas through the process of anaerobic digestion. The pomace contains larger amounts of lignin, that cannot be decomposed under anaerobic conditions, which is a limitation of this raw material [146]. Potential improvements in this process are constant stirring in the reactor [147] or previous extraction of polyphenols from the pomace [35].

An interesting study [148] dealt with the use of grape pomace to obtain biogas, which is then used to generate electricity. Namely, during the intensive processing of wine, which lasts about three months, the energy needs of the winery are great, most of which goes to cooling during must fermentation, which must not be avoided because low temperatures keep the key components of must. The dynamic model of a biogas-powered microturbine shows that the waste generated by the winery itself can be immediately converted into electricity and used on site, which is a practical and vivid example of circular economy in action.

This approach has potential even at the micro level, ie. both small and medium-sized enterprises could use the energy thus obtained, according to Fabbri et al. [149]. Successful experiments ElAchkar et al. [150] and Eleutheria et al. [151] showed that Scale-up of such systems is also possible, which generally leads to the conclusion that grape pomace, alone or with other by-products (e.g. sediment or wine lees) must not be wasted, but can be used efficiently in different ways.

\subsubsection{Additional fermentation processes of grape pomace}

Due to the presence of lignocellulosic polysaccharides, grape pomace can represent a source for the production of glucose, xylose and other monomeric sugars by acid hydrolysis. Glucose in grape pomace can be used as a substrate for the production of lactic acid through homolactic fermentation using the bacterium Lactobacillus pentosus [44], and also for the production of biosurfactants, which show good hydrophobic and emulsifying properties [152,153].

Campanella et al. [154] showed that probiotic cultures of lactic acid bacteria and bifidobacteria grow well on grape pomace substrates enriched with $1 \%$ glucose. In vitro studies of antioxidant activity, as well as simulation of gastrointestinal conditions, have shown that pomace is a suitable carrier for strains of probiotic bacteria, which represents another possible application of pomace.

Grape pomace can be an excellent substrate for the production of enzymes by solid-state fermentation. Aspergillus awamori has been used to produce hydrolytic enzymes [155], xylanases and pectinases [156]. These enzymes can further be used to clarify juices [157], which represents a direct revaluation of by-products and a reduction in their amount in industrial plants.

\subsection{Agricultural and ecological application of grape pomace}

Wine waste can potentially be used for soil conditioning and as a fertilizer [48]. During composting, organic matter undergoes microbiological processes in mesophilic and then in thermophilic conditions. The transition to thermophilic conditions may be an obstacle to the use of grape pomace due to the low $\mathrm{pH}$ value that can inhibit this transition [28]. The solution of this problem took the direction of the joint composting of pomace with other raw materials. The mixture of hydrolyzed grape pomace and wine lees showed good initial characteristics during composting of lignocellulosic waste, although the final results were similar for this mixture and raw grape pomace [158]. The use of compost from wine waste increases the percentage of organic matter, nutrient levels, microbiological biomass and improves the physical properties of the soil such as aeration and water retention capacity [48]. According to Arvanitoyannis et al. [48], the application of compost from agricultural waste in the soil can lead to problems related to the content of heavy metals.

One study [159] suggests that biochar obtained from grape pomace, as well as from other agricultural residues, can be used as a source of phosphorus in the soil, ie. that it can improve plant growth, taking into account that chemical composition of soil and other conditions also play a very important role. In addition to phosphorus, biochar produced by pyrolysis from grape pomace also contains $\mathrm{N}, \mathrm{K}, \mathrm{Ca}$, as well as significant amounts of $\mathrm{Na}, \mathrm{Mg}, \mathrm{Fe}, \mathrm{Zn}$ and other nutrients [160]. 
Wine waste can be a potential adsorbent for heavy metals $[48,161]$, thanks to carboxylin, amino and hydroxyl groups from proteins or phenols that can bind metal ions.

\section{CONCLUSION}

Taking into account the predictions of population growth on Earth, the food industry is expected to increase production enormously, which inevitably brings with it an increase in the amount of waste generated. Unlike some other industries, this is a potential raw material that contains invaluable amounts of bioactive substances, which would be a shame not to use. The aim of this paper was to show that waste from the food industry is not waste in the true sense of the word, but a raw material that can be included in other processes, thus satisfying the basic principles of circular economy - regeneration and circulation.

Organic components of waste of plant origin are interesting for further utilization, because they contain large amounts of highly valuable molecules. The wine industry, as the main industry when it comes to grapes as a raw material, generates large amounts of this kind of waste. In this review of the literature, various innovative solutions are given that show what to do next with the by-products of wine production, primarily grape pomace. In addition to the classic and well-known use in the spirits industry, through composting or as an addition to livestock food, new solutions are presented - pomace as a significant bioenergy source, utilization of the most important substances from pomace, such as polyphenolic compounds, dietary fiber, tartaric acid, oils, then a review of pomace as a raw material for obtaining biofuels, enzymes, biosurfactants, etc.

Since the possibilities of usage in only one branch of the food industry are so diverse, which is confirmed by the mentioned references, it remains only to suggest that examples of good practice, such as circular economy, should not be forgotten or theorized, but become a reality through legal regulations.

\section{Acknowledgements}

This paper was realized as a result of research within the contract on realization and financing of scientific research work in 2020 between the Faculty of Agriculture in Belgrade and the Ministry of Education, Science and Technological Development of the Republic of Serbia, evidentiary contract number: 451-03-68/2020-14/200116.

\section{REFERENCES}

[1] Z.Zavargo, A.Jokić (2010) Koncept nulte emisije (Zero Emissions Concept), Journal of Engineering\&Processing Management, 2(2), 79-89.

[2] M.Drljača (2015) Tranzicija linearne u kružnu ekonomiju (Koncept učinkovitog upravljanja otpadom). III. International Conference, Proceedings Book Quality System Condition for Successful Business and Competitiveness, Association for Quality and Standardization of Serbia, Vrnjačka Banja, p.35-44.

[3] K.Hobson (2016) Closing the loop or squaring the circle? Locating generative spaces for the circular economy, Progress in Human Geography, 40(1), 88-104.

[4] M.Niero, et al. (2017) Combining eco-efficiency and eco-effectiveness for continuous loop beverage packaging systems: lessons from the Carlsberg circular community, Journal of Industrial Ecology, 21(3), 742-753.

[5] J.Singh, I.Ordonez (2016) Resource recovery from post-consumer waste: important lessons for the upcoming circular economy, Journal of Cleaner Production, 134, 342-353.

[6] F.Blomsma, G.Brennan (2017) The emergence of circular economy: a new framing around prolonging resource productivity, Journal of Industrial Ecology, 21(3), 603-614.

[7] J.Korhonen, C.Nuur, A.Feldmann, S.Eshetu Birkie (2018) Circular economy as an essentially contested concept, Journal of Cleaner Production, 175, 544-552.

[8] R.Domínguez-Perles, D.A.Moreno, C.GarcíaViguera (2018) Waking up from four decades' long dream of valorizing Agro-food byproducts: Toward practical applications of the gained knowledge, Journal of Agricultural and Food Chemistry, 66, 3069-3073.

[9] S.Mitrović, I.Radosavljević, M.Veselinov (2017) Cirkularna ekonomija kao šansa za razvoj Srbije, Misija OSCE u Srbiji, Available at: https://www.osce.org/sr/serbia/292311.

[10] N.Mirabella, V.Castellani, S.Sala (2014) Current options for the valorization of food manufacturing waste: a review, Journal of Cleaner Production, 65, 28-41.

[11] L.Bhatia, S.Johri, R.Ahmad (2012) An economic and ecological perspective of ethanol production from renewable agro waste: a review. AMB Express, 2, 65-74.

[12] A.J.Van der Goot, P.J.M.Pelgrom, J.A.M.Berghout, M.E.J.Geerts, L.Jankowiak, N.A.Hardt, J. Keijer, M.A.I. Schutyser, C.V. Nikiforidis, R.M. Boom, (2016) Concepts for further sustainable production of foods, Journal of Food Engineering, 168, 42-51.

[13] O.Santana-Méridas, A.González-Coloma, R.Sánchez-Vioque (2012) Agricultural residues as a source of bioactive natural producs, Phytochemistry Reviews, 11, 447-466.

[14] C.M.Jasch (2009) Environmental and Material Flow Cost Accounting: Principles and Procedures, Springer, Netherlands. 
[15] M.C.Galanakis (2012) Recovery of high addedvalue components from food wastes: conventional, emerging technologies and commercialized applications, Trends in Food Science\&Technology, 26, 68-87.

[16] L.J.Yu, M.S.L.Brooks (2016) Food industry protein by-products and their applications. Chapter 7, Protein Byproducts, Academic Press, p.120-132.

[17] M.R.Kosseva (2011) Management and processing of food wastes, Advances in Food and Nutrition Research, 58, 57-136.

[18] G.Laufenberg, B.Kunz, M.Nystroem (2003) Transformation of vegetable waste into value added products: (A) the upgrading concept; (B) practical implementations, Bioresource Technology, 87, 167198.

[19] J.K.Arora, S.S.Marwaha, R.Grover (2002) Biotechnology in Agriculture and Environment, Asiatech Publishers, New Delhi, p.231-265.

[20] A.E.Ghaly, V.V.Ramakrishnan, M.S.Brooks, S.M.Budge, D.Dave (2013) Fish processing wastes as a potential source of proteins amino acids and oils: a critical review, Journal of Microbial and Biochemical Technology, 5(4), 107-129.

[21] V.K.Joshi (2002) Food processing industries waste: Opportunities, technologies, challenges and future strategies. In: Arora, J.K., Marwaha, S.S., and Grover, R. (eds.) Biotechnology in Agriculture and Environment, Asiatech Publishers, New Delhi, p.129-148,

[22] C.S.K.Lin, L.A.Pfaltzgraff, L.Herrero-Davila, E.B. Mubofu, S.Abderrahim, J.H.Clark, A.A.Koutinas, N. Kopsahelis, K.Stamatelatou, F.Dickson, S. Thankappan, Z.Mohamed, R.Brocklesby, R.Luque (2013) Food waste as a valuable resource for the production of chemicals, materials and fuels. Current situation and global perspective, Energy\&Environmental Science, 6, 426-435.

[23] K.Fischer, H.P.Bipp (2005) Generation of organic acids and monosaccharides by hydrolytic and oxidative transformation of food processing residues,Bioresource Technology, 96, 831-842.

[24] D.R.Kammerer, J.Kammerer, R.Valet, R.Carle (2014) Recovery of polyphenols from the byproducts of plant food processing and application as valuable food ingredients, Food Research International, 65, 2-12.

[25] J.Prakash (1996) Rice bran proteins: properties and food uses, Critical Reviews in Food Science and Nutrition 36, 537-552.

[26] W.C.Vong, S.Q.Liu (2016) Biovalorisation of okara (soybean residue) for food and nutrition, Trends in Food Science \& Technology, 52, 139-147.

[27] C.Beres, G.N.S.Costa, I.Cabezudo, N.K. da SilvaJames, A.S.C.Teles, A.P.G.Cruz, C.Mellinger-Silva, R.V.Tonon, L.M.C.Cabral, S.P.Freitas (2017) Towards integral utilization of grape pomace from winemaking process: A review, Waste Management, 68, 581-594.

[28] R.A. Muhlack, R.Potumarthi, D.W.Jeffery (2018) Sustainable wineries through waste valorisation: A review of grape marc utilisation for value-added products, Waste Management, 72, 99-118. Available at: https://doi.org/10.1016/j.wasman. 2017. 11.011
[29] K.L.Christ, R.L.Burrit (2013) Critical environmental concerns in wine production: an integrative review, Journal of Cleaner Production, 53, 232-242.

[30] A.Brenes, A.Viveros, S.Chamorro, I.Arija (2016) Use of polyphenol-rich grape byproducts in monogastric nutrition. A review, Animal Feed Science and Technology, 211, 1-7.

[31] R.Devesa-Rey, X.Vecino, J.L.Varela-Alende, M.T. Barral, J.M.Cruz, A.B.Moldes (2011) Valorization of winery wastes vs. The cost of not recycling, Waste Management, 31, 2327-2335.

[32] K.Dwyer, F.Hosseinian, M.Rod (2014) The market potential of grape waste alternatives, Journal of Food Research, 3, 91-106.

[33] J.A.S.Mendes, A.M.R.B.Xavier, D.V.Evtuguin, L.P.C.Lopes (2013) Integrated utilization ofgrape skins from white grape pomaces, Industrial Crops and Products, 49, 286-291.

[34] J.Hixson, E.Wilkes, P.Smith, K.Forsyth (2014) Understanding the composition of grape marc and its potential as a livestock feed supplement, The Australian Wine Research Institute (AWRI) Technical Review, 213, 11-15.

[35] G.A. Martinez, S. Rbecchi, D.Decorti, J.M.B. Domingos, A.Natolino, D.Del Rio, L.Bertin, C.Da Porto, F.Fava (2016) Towards multi-purpose biorefinery platforms for the valorisation of red grape pomace: production of polyphenols, volatile fatty acids, polyhydroxyalkanoates and biogas, Green chemistry, 18, 261-270.

[36] S.Chamorro, A.Viveros, I.Alvarez, E.Vega, A.Brenes (2012) Changes in polyphenol and polysaccharide content of grape seed extract and grape pomace after enzymatic treatment, Food Chemistry, 133, 308-314.

[37] K.S.Duba, A.A.Casazza, H Ben Mohamed, P. Perego, L.Fiori (2015) Extraction of polyphenols from grape skins and defatted grape seeds using subcritical water: Experiments and modeling, Food and Bioproducts Processing, 94, 29-38.

[38] L.Casas, C.Mantell, M.Rodríguez, E.J.M.D.L. Ossa, A. Roldán, I.D.Ory et al. (2010) Extraction of resveratrol from the pomace of Palomino fino grapes by supercritical carbon dioxide, Journal of Food Engineering, 96, 304/308.

[39] L.Fernandes, S.Casal, R.Cruz, J.A.Pereira, E.Ramalhosa (2013) Seed oils of ten traditional Portuguese grape varieties with interesting chemical and antioxidant properties, Food Research International, 50, 161-166.

[40] L.Fiori, V.Lavelli, K.S.Duba, P.S.C.Sri Harsha, H.B.Mohamed, G.Guella (2014) Supercritical $\mathrm{CO}_{2}$ extraction of oil from seeds of six grape cultivars: Modeling of mass transfer kinetics and evaluation of lipid profiles and tocol contents, The Journal of Supercritical Fluids, 94, 71-80.

[41] C.Beres, F.F.Simas-Tosin, I.Cabezudo, S.P.Freitas, M.lacomini, C.Mellinger-Silva, L.M.Cabral (2016) Antioxidant dietary fibre recovery from Brazilian Pinot noir grape pomace, Food Chemistry, 201, 145-152.

[42] A.Rózek, I.Achaerandio, C.Güell, F.López, M.Ferrando (2010) Use of commercial grape phenolic extracts to supplement solid foodstuff, LWT- Food Science and Technology, 43, 623-631. 
[43] F.B.Shinagawa, F.C.Santana, L.R.O.Torres, J.Mancini-Filho (2015) Grape seed oil: a potential functional food? Journal of Food Science and Technology, 35, 399-406.

[44] O.M.P. Rivera, A.B.Moldes, A.M.Torrado, J.M Dominguez (2007) Lactic acid and biosurfactants production from hydrolyzed distilled grape marc, Process Biochemistry, 42(6), 1010-1020.

[45] J.García-Lomillo, M.L. González-SanJosé, R. Del Pino-García, M.D. Rivero-Pérez, P. MuñizRodríguez (2014) Antioxidant and antimicrobia properties of wine by-products and their potential uses in the food industry. Journal of Agricultural and Food Chemistry, 62, 12595-12602.

[46] F. Rezaei, J.S. VanderGheynst (2010) Critical moisture content for microbial growth in dried foodprocessing residues, Journal of the Science of Food and Agriculture, 90, 2000-2005.

[47] D.K. Mishra, K.D. Dolan, L.Yang (2008) Confidence intervals for modeling anthocyanin retention in grape pomace during nonisothermal heating, Journal of Food Science, 73, E9-E15.

[48] I.S. Arvanitoyannis, D. Ladas, A. Mavromatis (2006) Potential uses and applications of treated wine waste: a review, International Journal of Food Science \& Technology, 41, 475-487.

[49] I.S. Arvanitoyannis, D. Ladas, A. Mavromatis (2006) Wine waste treatment methodology. International Journal of Food Science \& Technology, 41, 11171151.

[50] F.T.Santos, P.Goufo, C.Santos, D.Botelho, J. Fonseca, A.Queirós, M.S.S.M.Costa, H.Trindade (2016) Comparison of five agro-industrial wastebased composts as growing media lettuce: Effect on yield, phenolic compounds and vitamin C, Food Chemistry, 209, 293-301.

[51] B.Digman, D.S.Kim (2008) Review: alternative energy from food processing wastes, Environmental Progress, 27, 524-537.

[52] A.Celma, S.Rojas, F.López-Rodríguez (2007) Waste-to-energy possibilities for industrial olive and grape by-products in Extremadura, Biomass Bioenergy 31, 522-534.

[53] P.McKendry (2002) Energy production from biomass (part 2): conversion technologies, Bioresource Technology, 83, 47-54.

[54] E.lakovou, A.Karagiannidis, D.Vlachos, A.Toka, A Malamakis (2010) Waste biomass-to-energy supply chain management: a critical synthesis, Waste Management, 30, 1860-1870.

[55] P. Guo, W.L.Saw, P.J. van Eyk, E.B. Stechel, R. de Nys, P.J. Ashman, G.J. Nathan (2017) Gasification reactivity and physicochemical properties of the chars from raw and torrefied wood, grape marc, and macroalgae, Energy Fuels, 31, 2246-2259.

[56] C.Marculescu, S.Ciuta, (2013) Wine industry waste thermal processing for derived fuel properties improvement, Renewable Energy, 57, 645-652.

[57] M.Miranda, J.Arranz, S.Román, S.Rojas, I. Montero, M.López, J.Cruz, (2011) Characterization of grape pomace and pyrenean oak pellets, Fuel Processing Technology, 92, 278-283.
[58] J.J. Hernández, G. Aranda-Almansa, A. Bula (2010) Gasification of biomass wastes in an entrained flow gasifier: effect of the particle size and the residence time, Fuel Processing Technology, 91, 681-692.

[59] M. Lapuerta, J.J. Hernández, A. Pazo, J. López (2008) Gasification and cogasification of biomass wastes: effect of the biomass origin and the gasifier operating conditions, Fuel Processing Technology, 89, 828-837.

[60] L. Wang, M.Becidan, Ø. Skreiberg (2012) Sintering behavior of agricultural residues ashes and effects of additives, Energy Fuels, 26, 5917-5929.

[61] J. Brammer, A. Bridgwater (2002) The influence of feedstock drying on the performance and economics of a biomass gasifier-engine $\mathrm{CHP}$ system, Biomass Bioenergy, 22, 271-281.

[62] W.H.Chen, J. Peng, X.T.Bi (2015) A state-of-the-art review of biomass torrefaction, densification and applications, Renewable and Sustainable Energy Reviews, 44, 847-866.

[63] M. Pala, I.C. Kantarli, H.B.Buyukisik, J.Yanik (2014) Hydrothermal carbonization and torrefaction of grape pomace: a comparative evaluation, Bioresource Technology, 161, 255-262.

[64] M.Kaltschmitt, D.Thran, K.Smith (2004) Renewable energy from biomass, Encyclopedia of Physical Science and Technology, 203, 28.

[65] A.Kumar, D.D.Jones, M.A.Hanna (2009) Thermochemical biomass gasification: a review of the current status of the technology, Energies, 2, 556-581.

[66] P.Haro, F.Trippe, R.Stahl, E.Henrich (2013) Biosyngas to gasoline and olefins via DME - a comprehensive techno-economic assessment, Applied Energy, 108, 54-65.

[67] T.R.Brown, Y.Zhang, G.Hu, R.C.Brown (2012) Techno-economic analysis of biobased chemicals production via integrated catalytic processing, Biofuels, Bioproducts and Biorefining, 6, 73-87.

[68] T.Nussbaumer (2003) Combustion and cocombustion of biomass: fundamentals, technologies, and primary measures for emission reduction, Energy Fuels 17, 1510-1521.

[69] A.C.Caputo, M.Palumbo, P.M.Pelagagge, F. Scacchia (2005) Economics of biomass energy utilization in combustion and gasification plants: effects of logistic variables, Biomass Bioenergy 28 , 35-51.

[70] S.Ravelli, A.Perdichizzi, G.Barigozzi (2008) Description, applications and numerical modelling of bubbling fluidized bed combustion in wastetoenergy plants, Progress in Energy and Combustion Science (PECS), 34, 224-253.

[71] E. Benetto, C. Jury, G. Kneip, I. Vázquez-Rowe, V. Huck, F. Minette (2015) Life cycle assessment of heat productionfromgrapemarc pellets, Journal of Cleaner Production, 87, 149-158.

[72] R.G.Fernández, C.P.García, A.G.Lavín, J.L.B. de las Heras (2012) Study of main combustion characteristics for biomass fuels used in boilers, Fuel Processing Technology, 103, 16-26.

[73] A.Bridgwater (1995) The technical and economic feasibility of biomass gasification for power generation, Fuel, 74, 631-653. 
[74] L.Wang, C.L.Weller, D.D.Jones, M.A.Hanna (2008) Contemporary issues in thermal gasification of biomass and its application to electricity and fuel production, Biomass Bioenergy, 32, 573-581.

[75] J.Encinar, F.Beltran, A.Bernalte, A.Ramiro, J. Gonzalez (1996) Pyrolysis of two agricultural residues: olive and grape bagasse. Influence of particle size and temperature, Biomass Bioenergy 11, 397-409.

[76] H.Wijngaard, M.B.Hossain, D.K.Rai, N.Brunton (2012) Techniques to extract bioactive compounds from food by-products of plant origin, Food Research International, 46, 505-513.

[77] A.Hanganu, M.C.Todasca, N.A.Chira, M.Maganu, S.Rosca (2012) The compositional characterisation of Romanian grape seed oils using spectroscopic methods, Food Chemistry, 134, 2453-2458.

[78] J.Lachman, A.Hejtmankova, J.Taborsky, Z Kotikova, V.Pivec, R.Stralkova, A.Vollmannova, T. Bojnanska, M.Dedina (2015) Evaluation of oil content and fatty acid composition in the seed of grapevine varieties, LWT - Food Science and Technology, 63, 620-625.

[79] C.Da Porto, E.Porretto, D.Decorti (2013) Comparison of ultrasound-assisted extraction with conventional extraction methods of oil and polyphenols from grape (Vitis vinifera L.) seeds, Ultrasonics Sonochemistry, 20, 1076-1080.

[80] M.Ferri, S.Bin, V.Vallini, F.Fava, E.Michelini, A. Roda, G.Minnucci, G.Bucchi, A.Tassoni (2016) Recovery of polyphenols from red grape pomace and assessment of their antioxidant and anticholesterol activities, New Biotechnology, 33, 338344.

[81] A.R.Fontana, A.Antoniolli, R.Bottini (2013) Grape pomace as a sustainable source of bioactive compounds: extraction, characterization, and biotechnological applications of phenolics, Journal of Agricultural and Food Chemistry, 61, 8987-9003.

[82] A.Teixeira, N.Baenas, R.Dominguez-Perles, A. Barros, E.Rosa, D.A.Moreno, C.Garcia-Viguera (2014) Natural bioactive comounds from winery byproducts as health promoters: A review, International Journal of Molecular Sciences (IJMS), $15,15638-15678$.

[83] J.Garcia-Lomillo, M.L.Gonzalez-SanJose (2016) Aplications of wine pomace in the food industry: Approaches and functions, Comprehensive Reviews in Food Science and Food Safety, 16, 322.

[84] A.L.Waterhouse, G.L.Sacks, D.W.Jeffery (2016) Introduction to Phenolics, Understanding Wine Chemistry, John Wiley \& Sons Ltd., 99-104.

[85] H.El Gharras (2009) Polyphenols: food sources, properties and applications-a review, International Journal of Food Science \& Technology, 44, 25122518.

[86] D.Kammerer, A.Claus, R.Carle, A. Schieber (2004) Polyphenol screening of pomace from red and white grape varieties (Vitis vinifera L.) by HPLC-DADMS/MS, Journal of Agricultural and Food Chemistry, 52, 4360-4367.

[87] S.González-Manzano, J.C.Rivas-Gonzalo, C. Santos-Buelga (2004) Extraction of flavan-3-ols from grape seed and skin into wine using simulated maceration, Analytica Chimica Acta, 513, 283-289.

[88] M.Garcia-Marino, J.C.Rivas-Gonzalo, E.lbanez, C Garcia-Moreno (2006) Recovery of catechins and proanthocyanidins from winery by-products using subcritical water extraction, Analytica Chimica Acta, $563,44-50$.

[89] M.Otero-Pareja, L.Casas, M.Fernández-Ponce, C. Mantell, E. Ossa (2015) Green extraction of antioxidants from different varieties of red grape pomace, Molecules, 20, 9686.

[90] C.Garcia-Jares, A.Vazquez, J.P.Lamas, M.Pajaro, M.Alvarez-Casas, M.Lores (2015) Antioxidant white grape seed phenolics: pressurized liquid extracts from different varieties, Antioxidants, 4, 737-749.

[91] M.Corrales, S.Toepfl, P.Butz, D.Knorr, B.Tauscher (2008) Extraction of anthocyanins from grape byproducts assisted by ultrasonics, high hydrostatic pressure or pulsed electric fields: a comparison, Innovative Food Science and Emerging Technologies (IFSET), 9, 85-91.

[92] H.B.Mohamed, K.S.Duba, L.Fiori, H Abdelgawed, I. Tlili, T.Tounekti, A.Zrig (2016) Bioactive compounds and antioxidant activities of different grape (Vitis vinifera $L$.) seed oils extracted by supercritical CO2 and organic solvent, LWT - Food Science and Technology, 74, 557-562.

[93] A.Liazid, R.F.Guerrero, E.Cantos, M.Palma, C.G. Barroso (2011) Microwave assisted extraction of anthocyanins from grape skins, Food Chemistry, 124, 1238-1243.

[94] K.Krishnaswamy, V.Orsat, Y.Gari'epy, K. Thangavel (2013) Optimization of microwaveassisted extraction of phenolic antioxidants from grape seeds (Vitis vinifera), Food and Bioprocess Technology, 6, 441-455.

[95] A.Brenes, A.Viveros, S.Chamorro, I.Arija (2016) Use of polyphenol-rich grape byproducts in monogastric nutrition. A review, Animal Feed Science and Technology, 211, 1-7.

[96] J.M.Lorenzo, J.Sineiro, I.R.Amado, D.Franco (2014) Influence of natural extracts on the shelf life of modified atmosphere-packaged pork patties, Meat Science, 96, 526-534.

[97] A.S.Ferreira, C.Nunes, A.Castro, P.Ferreira, M.A. Coimbra (2014) Influence of grape pomace extract incorporation on chitosan films properties, Carbohydrate Polymers, 113, 490-499.

[98] B.O.Ozen, M.Eren, A.Pala, I.Ozmen, A.Soyer (2011) Effect of plant extracts on lipid oxidation during frozen storage of minced fish muscle, International Journal of Food Science \& Technology, 46, 724-731.

[99] J.Surh, E.Koh (2014) Effects of four different cooking methods on anthocyanins, total phenolics and antioxidant activity of black rice, Journal of the Science of Food and Agriculture, 94, 3296-3304.

[100] C.Xu, Y.Yagiz, S.Marshall, Z. Li, A.Simonne, J.Lu, M.R.Marshall, et al. (2015) Application of muscadine grape (Vitis rotundifolia Michx.) pomace extract to reduce carcinogenic acrylamide, Food Chemistry, 182, 200-208.

[101] Y.Xu, S.Burton, C.Kim, E. Sismour (2016) Phenolic compounds, antioxidant, and antibacterial 
properties of pomace extracts from four Virginiagrown grapes varieties, Food Science \& Nutrition, 4, 125-133.

[102] J.M.Silvan, E.Mingo, M.Hidalgo, S. de PascualTeresa, A.V.Carrascosa, A.J. Martinez-Rodriguez (2013) Antibacterial activity of a grape seed extract and its fractions against Campylobacter spp, Food Control, 29, 25-31.

[103] J.Wittenauer, S.Mäckle, D. Sußmann, U. Schweiggert-Weisz, R.Carle (2015) Inhibitory effects of polyphenols from grape pomace extract on collagenase and elastase activity, Fitoterapia, $101,179-187$

[104] C.Hoye, C.F.Ross (2011) Total phenolic content, consumer acceptance, and instrumental analysis of bread made with grape seed flour, Journal of Food Science, 76, S428-S436.

[105] M.Aghamirzaei, S.H. Peighambardoust, S. Azadmard-Damirchi, M. Majzoobi (2015) Effects of grape seed powder as a functional ingredient on flour physicochemical characteristics and dough rheological properties, Journal of Agricultural Science and Technology (JAST), 17, 365-373.

[106] R.Meral, I.S.Dogan (2013) Grape seed as a functional food ingredient in bread-making, International Journal of Food Sciences and Nutrition, 64, 372-379.

[107] I.Smith, J.Yu (2015) Nutritional and sensory quality of bread containing different quantities of grape pomace from different grape cultivars, EC Nutrition (ECNU), 2, 291-301.

[108] S.Mildner-Szkudlarz, R. Zawirska-Wojtasiak, A.Szwengiel, M.Pacynski (2011) Use of grape byproduct as a source of dietary fibre and phenolic compounds in sourdough mixed rye bread, International Journal of Food Science \& Technology (IJFST), 46, 1485-1493.

[109] S.Mildner-Szkudlarz, J.Bajerska, R.ZawirskaWojtasiak, D.Gorecka (2012) White grape pomace as a source of dietary fibre and polyphenols and its effect on physical and nutraceutical characteristics of wheat biscuits, Journal of the Science of Food and Agriculture, 93, 389-395.

[110] Z.Aksoylu, O.Cagindi, E.Kose (2015) Effects of blueberry, grape seed powder and poppy seed incorporation on physicochemical and sensory properties of biscuit, Journal of Food Quality, 38, 164-174.

[111] S.Mildner-Szkudlarz, A.Siger, A.Szwengiel, J.Bajerska (2015) Natural compounds from grape by-products enhance nutritive value and reduce formation of CML in model muffins, Food Chemistry 172, 78-85.

[112] D.M.Oliveira, D.R.Marques, A. Kwiatkowski, A.R.G.Monteiro, E.Clemente (2013) Sensory analysis and chemical characterization of cereal enriched with grape peel and seed flour, Acta Scientiarum Technology, 35, 427-431.

[113] R.Walker, A.Tseng, G. Cavender, A.Ross, Y.Zhao (2014) Physicochemical, nutritional, and sensory qualities of wine grape pomace fortified baked goods, Journal of Food Science, 79, S1811-S1822.
[114] M.U.Rosales Soto, K.Brown, C.F.Ross (2012) Antioxidant activity and consumer acceptance of grape seed flour-containing food products, International Journal of Food Science \& Technology (IJFST), 47, 592-602.

[115] B.Aliakbarian, M.Casale, M.Paini, A.A.Casazza, S.Lanteri, P.Perego (2015) Production of a novel fermented milk fortified with natural antioxidants and its analysis by NIR spectroscopy, LWT - Food Science and Technology, 62, 376-383.

[116] V.Chouchouli,N. Kalogeropoulos, S.J.Konteles, E.Karvela, D.P.Makris, V.T. Karathanos (2013) Fortification of yoghurts with grape (Vitis vinifera) seed extracts, LWT - Food Science and Technology, 53, 522-529.

[117] R.Marchiani, M.Bertolino, S. Belviso, M.Giordano, D.Ghirardello, L.Torri, M. Piochi, G. Zeppa (2016) Yogurt enrichment with grape pomace: effect of grape cultivar on physicochemical, microbiological and sensory properties, Journal of Food Quality, 39, 77-89.

[118] A.Tseng, Y.Zhao (2013) Wine grape pomace as antioxidant dietary fibre for enhancing nutritional value and improving storability of yogurt and salad dressing, Food Chemistry, 138, 356-365.

[119] R.Marchiani, M.Bertolino, D. Ghirardello, P.L.H. McSweeney, G.Zeppa (2015) Physicochemical and nutritional qualities of grape pomace powderfortified semi-hard cheeses, Journal of Food Science and Technology (JFST), 53, 1-12.

[120] Joint FAO/WHO Food Standards Programme, 2010. Secretariat of the CODEX Alimentarius Commission: CODEX Alimentarius (CODEX) Guidelines on Nutrition Labeling CAC/GL 2-1985 as Last Amended 2010. FAO, Rome.

[121] M.R.González-Centeno, C. Rosselló, S.Simal, M.C.Garau, F.López, A. Femenia (2010) Physicochemical properties of cell wall material obtained from ten grape varieties and their byproducts: grape pomaces and stems, LWT - Food Science and Technology, 43, 1580-1586.

[122] S.Y.Kim, S.M.Jeong, W.P.Park, K.C.Nam, D.U. Ahn, S.C.Lee (2006) Effect of heating conditions of grape seeds on the antioxidant activity of grape seed extracts, Food Chemistry, 97(3), 472-479.

[123] F.Zhu, B.Du, L.Zheng, J.Li (2015) Advance on the bioactivity and potential applications of dietary fibre from grape pomace, Food Chemistry, 186, 207212.

[124] R.Minjares-Fuentes, A.Femenia, M.C.Garau, J.A.Meza-Velázquez, S.Simal, C. Rosselló (2014) Ultrassound-assisted extraction of pectins from grape pomace using citric acid: A response surface methodology approach, Carbohydrate Polymers, 106, 179-189.

[125] Q.Deng, M.H.Penner, Y.Zha (2011) Chemical composition of dietary fibre and polyphenols of five different varieties of wine grape pomace skins. Food Res Int. Food Research International, 44, 2712-2720.

[126] K.N.Kontogiannopoulos, S.I. Patsios, A.J. Karabelas (2016) Tartaric acid recovery from wine- 
ry lees using cation exchange resin: Optimization by response surface methodology, Separation and Purification Technology, 165, 32-41.

[127] C.Nurgel, A.Canbas (1998) Production of tartaric acid from pomace of some Anatolian grape cultivars, American Journal of Enology and Viticulture, 49, 95-99.

[128] A. Versari, M. Castellari, U. Spinabelli, S. Galassi (2001) Recovery of tartaric acid from industrial enological wastes, Journal of Chemical Technology \& Biotechnology, 76, 485-488.

[129] B.Rivas, A.Torrado, A.B.Moldes, J.M.Domínguez (2006) Tartaric acid recovery from distilled lees and use of the residual solid as an economic nutrient for Lactobacillus, Journal of Agricultural and Food Chemistry, 54, 7904-7911.

[130] J.M.Salgado, N.Rodriguez, S. Cortés, J.M.Dominguez (2010) Improving downstream processes to recover tartaric acid, tartrate and nutrients from vinasses and formulation of inexpensive fermentative broths for xylitol production, Journal of the Science of Food and Agriculture, 90 (13), 2168-2177.

[131] F.G.Braga, F.A.Lencart e Silva, A.Alves (2002) Recovery of winery by-products in the Douro demarcated region: production of calcium tartrate and grape pigments, American Journal of Enology and Viticulture, 53, 41-45.

[132] I.I.Rockenbach, EJungfer, C. Ritter, B.SantiagoSchübel, B.Thiele, R.Fett, R. Galensa (2012) Characterization of flavan-3-ols in seeds of grape pomace by CE, HPLC-DAD-MS $\mathrm{n}$ and LC-ESIFTICR-MS, Food Research International, 48, 848855.

[133] J.M. Luque-Rodríguez, M.L. De Castro, P. PérezJuan (2005) Extraction of fatty acids from grape seed by superheated hexane, Talanta, 68, 126130.

[134] P.Hanmoungjai, L.Pyle, K. Niranjan (2000) Extraction of rice bran oil using aqueous media. Journal of Chemical Technology \& Biotechnology, 75, 348-352.

[135] N.Rombaut, R.Savoire, B. Thomasset, T.Belliard, J.Castello, E.Van Hecke, J. Lanoiselle (2014) Grape seed oil extraction: Interest of supercritical fluid extraction and gas-assisted mechanical extraction for enhancing polyphenol coextraction in oil, Comptes Rendus Chimie (CR CHIM), 17, 284292.

[136] K.S.Duba, L.Fiori (2015) Supercritical $\mathrm{CO}_{2}$ extraction of grape seed oil: Effect of process parameters on the extraction kinetics, Journal of Supercritical Fluids, 98, 33-43.

[137] K.S.Duba, L.Fiori (2016) Solubility of grape seed oil in supercritical $\mathrm{CO}_{2}$ : Experiments and modeling, Journal of Chemical Thermodynamics, 100, 44-52.

[138] A.G.Sicaire, M.A.Vian, F.Fine, P. Carré, S.Tostain, F.Chemat (2016) Ultrasound induced green solvent extraction of oil from oleaginous seeds, Ultrasonics Sonochemistry, 31, 319-329.

[139] E.B.Özvural, H.Vural (2014) Which is the best grape seed additive for frankfurters: extract, oil or flour?, Journal of the Science of Food and Agriculture, 94, 792-797.
[140] P.Górnas, M.Rudzinska (2016) Seeds recovered from industry by-products of ninefruit species with a high potential utility as a source of unconventional oil for biodiesel and cosmetic and pharmaceutical sectors, Industrial Crops and Products, 83, 329338.

[141] K.R.Corbin, Y.S.Hsieh, N.S. Betts, C.S.Byrt, M.Henderson, J.Stork, S.DeBolt, G.B.Fincher, R.A.Burton (2015) Grape marc as a source of carbohydrates for bioethanol: chemical composition, pre-treatment and saccharification, Bioresource Technology, 193, 76-83.

[142] C.Da Porto (2002) Volatile composition of grappa low wines' using different methods and conditions of storage on an industrial scale, International Journal of Food Science \& Technology (IJFST), 37, 395-402.

[143] S.Cortés, J.M.Salgado, N. Rodríguez, J.M. Domínguez (2010) The storage of grape marc: limiting factor in the quality of the distillate, Food Control, 21, 1545-1549.

[144] L.lacumin, M.Manzano, F. Cecchini, S.Orlic, R. Zironi, G.Comi (2012) Influence of specific fermentation conditions on natural microflora of pomace in "Grappa" production, World Journal of Microbiology \& Biotechnology, 28, 1747-1759.

[145] N.Sarkar, S.K.Ghosh, S. Bannerjee, K.Aikat (2012) Bioethanol production from agricultural wastes: an overview, Renewable energy, 37, 19-27.

[146] E.Dinuccio, P.Balsari, F.Gioelli, S. Menardo (2010) Evaluation of the biogas productivity potential of some Italian agro-industrial biomasses, Bioresource Technology, 101, 3780-3783.

[147] V.N.Gunaseelan (2004) Biochemical methane potential of fruits and vegetable solid waste feedstocks, Biomass Bioenergy, 26, 389-399.

[148] C.Cáceres, R.Cáceres, D.Hein, M.Molina, J.Pia (2012) Biogas production from grape pomace: thermodynamic model of the process and dynamic model of the power generation system, International Journal of Hydrogen Energy, 37, 10111-10117.

[149] A.Fabbri, G.Bonifazi, S.Serranti (2015) Micro-scale energy valorization of grape marcs in winery production plants, Waste Management, 36, 156165.

[150] J.H.El Achkar, T.Lendormi, Z. Hobaika, D.Salameh, N.Louka, R.G.Maroun, J.L. Lanoisellé (2016) Anaerobic digestion of grape pomace: biochemical characterization of the fractions and methane production in batch and continuous digesters, Waste Management, 50, 275-282.

[151] N.Eleutheria, I.Maria, T.Vasiliki, E. Alexandros, A. Alexandros, D, Vasileios (2016) Energy recovery and treatment of winery wastes by a compact anaerobic digester, Waste Biomass Valorization, 7, 799-805.

[152] O. Portilla-Rivera, A. Torrado, J. Domínguez, A. Moldes (2008) Stability and emulsifying capacity of biosurfactants obtained from lignocellulosic sources using Lactobacillus pentosus, Journal of Agricultural and Food Chemistry, 56, 8074-8080.

[153] R.Paradelo, A.B.Moldes, J.M. Dominguez, M.A.T.Barral (2009) Reduction of water repellence 
of hydrophobic plant substrates using biosurfactant produced from hydrolyzed grape marc, Journal of Agricultural and Food Chemistry, 57, 4895-4899.

[154] D.Campanella, C.G.Rizzello, C. Fasciano, G.Gambacorta, D.Pinto, B.Marzani, N. Scarano, M.De Angelis, M.Gobbetti (2017) Exploitation of grape marc as functional substrate for lactic acid bacteria and bifidobacteria growth and enhanced antioxidant activity, Food Microbiology, 65, 25-35.

[155] C.Botella, I. De Ory, C.Webb, D. Cantero, A.Blandino (2005) Hydrolytic enzyme production by Aspergillus awamori on grape pomace, Biochemical Engineering Journal, 26, 100-106.

[156] C.Botella, A.Diaz, I.De Ory, C. Webb, A.Blandino (2007) Xylanase and pectinase production by Aspergillus awamori on grape pomace in solid state fermentation, Process Biochemistry, 42, 98101.

[157] A.B.Díaz, O.Alvarado, I. de Ory, I.Caro, A.Blandino (2013) Valorization of grape pomace and orange peels: improved production of hydrolytic enzymes for the clarification of orange juice, Food and Bioproducts Processing, 91, 580-586.

[158] R.Paradelo, A.B.Moldes, M.T. Barral (2013) Evolution of organic matter during the mesophilic composting of lignocellulosic winery wastes, J. Environ. Manage, Journal of Environmental Management, 116, 18-26.

[159] I.I.Manolikaki, A.Mangolis, E. Diamadopoulos (2016) The impact of biochars prepared from agricultural residues on phosphorus release and availability in two fertile soils, Journal of Environmental Management, 181, 536-543.

[160] A.Zabaniotou, P.Kamaterou, A. Pavlou, C. Panayiotou (2018) Sustainable bioeconomy transitions: Targeting value capture by integrating pyrolysis in a winery waste biorefinery, Journal of Cleaner Production, 172, 3387-3397.

[161] L.Yuan-shen, L.Cheng-chung, C.Chyow-san (2004) Adsorption of $\mathrm{Cr}$ (III) from wastewater by wine processing waste sludge, Journal of Colloid and Interface Science, 273, 95-101.

\section{IZVOD}

\section{CIRKULARNA EKONOMIJA U PREHRAMBENOJ INDUSTRIJI}

Koncept cirkularne ekonomije prevazilazi zastareli koncept linearne ekonomije, koji podrazumeva nekontrolisanu eksploataciju prirodnih resursa i protok materijala od fabrike preko korisnika do deponije. U cirkularnoj ekonomiji dolazi do zatvaranja kruga: proizvod - otpad - proizvod. Od industrije se očekuje da funkcioniše kao prirodni eko-sistem i da otpad iz jedne industrije postaje sirovina u drugoj tj. da podražava kruženje, odakle potiče naziv cirkularna. Generalno, cirkularna ekonomija je opšti pojam koji obuhvata sve aktivnosti koje smanjuju, ponovo koriste i recikliraju materijale u procesima proizvodnje, distribucije i potrošnje. Uzimajući u obzir predviđanja o rastu populacije na Zemlji, od industrije hrane se očekuje porast proizvodnje, koji neminovno sa sobom nosi $i$ povećanje količine generisanog otpada. Organske komponente otpada biljnog porekla interesantne su za dalje iskorišćenje, jer sadrže velike količine visoko vrednih molekula. Cilj rada bio je da se pokaže kako otpad iz prehrambene industrije nije otpad već sirovina koja se može uključiti u druge procese, osnovni principi cirkularne ekonomije - regenerativnost $i$ kruženje. Vinska industrija, kao glavna industrija kada se radi o grožđu kao sirovini, stvara velike količine ovakvog otpada. U ovom pregledu literature data su razna inovativna rešenja koja pokazuju šta dalje raditi sa nus-proizvodima dobijanja vina, pre svega komine grožđa. Osim iskorišćenja u industriji jakih pića, putem kompostiranja ili kao dodataka stočnoj hrani, prikazana su nova rešenja - komina kao značajan bioenergetski izvor, iskorišćenje najvažnijih supstanci iz komine, kao što su polifenolna jedinjenja, dijetetska vlakna, vinska kiselina, ulja, zatim osvrt na kominu kao sirovinu za dobijanje biogoriva, enzima, biosurfaktanata, itd.

Ključne reči: cirkularna ekonomija, prehrambena industrija, vinska industrija, komina.

\section{Pregledni rad}

Rad primljen: 02. 06. 2020.

Rad prihvaćen: 10. 07. 2020.

Rad je dostupan na sajtu: www.idk.prg.rs/casopis

(c) 2020 Authors. Published by Engineering Society for Corrosion. This article is an open access article distributed under the terms and conditions of the Creative Commons Attribution 4.0 International license (https://creativecommons.org/licenses/by/4.0/) 